\title{
Modulation of Ion Transport Across Plant Membranes by Polyamines: Understanding Specific Modes of Action Under Stress
}

\author{
Igor Pottosin ${ }^{1,2 *}$, Miguel Olivas-Aguirre ${ }^{2}$, Oxana Dobrovinskaya², Isaac Zepeda-Jazo ${ }^{3}$ \\ and Sergey Shabala ${ }^{1,4}$
}

${ }^{1}$ International Research Centre for Environmental Membrane Biology, Foshan University, Foshan, China, ${ }^{2}$ Biomedical Center. University of Colima, Colima, Mexico, ${ }^{3}$ Food Genomics Department, Universidad de La Ciénega del Estado de Michoacán de Ocampo, Sahuayo, Mexico, ${ }^{4}$ Tasmanian Institute for Agriculture, College of Science and Engineering, University of Tasmania, Hobart, TAS, Australia

\section{OPEN ACCESS}

Edited by:

Gerald Alan Berkowitz,

University of Connecticut,

United States

Reviewed by:

Rashid Ali,

United Arab Emirates University,

United Arab Emirates

Gerald Schoenknecht,

Oklahoma State University,

United States

*Correspondence: Igor Pottosin

pottosin@ucol.mx

Specialty section:

This article was submitted to

Plant Membrane Traffic and Transport,

a section of the journa

Frontiers in Plant Science

Received: 11 October 2020 Accepted: 14 December 2020

Published: 26 January 2021

Citation:

Pottosin I, Olivas-Aguirre M, Dobrovinskaya O, Zepeda-Jazo I and Shabala S (2021) Modulation of Ion Transport Across Plant Membranes

by Polyamines: Understanding

Specific Modes of Action Under

Stress. Front. Plant Sci. 11:616077.

doi: 10.3389/fp/s.2020.616077
This work critically discusses the direct and indirect effects of natural polyamines and their catabolites such as reactive oxygen species and $\gamma$-aminobutyric acid on the activity of key plant ion-transporting proteins such as plasma membrane $\mathrm{H}^{+}$and $\mathrm{Ca}^{2+}$ ATPases and $\mathrm{K}^{+}$-selective and cation channels in the plasma membrane and tonoplast, in the context of their involvement in stress responses. Docking analysis predicts a distinct binding for putrescine and longer polyamines within the pore of the vacuolar TPC1/SV channel, one of the key determinants of the cell ionic homeostasis and signaling under stress conditions, and an additional site for spermine, which overlaps with the cytosolic regulatory $\mathrm{Ca}^{2+}$-binding site. Several unresolved problems are summarized, including the correct estimates of the subcellular levels of polyamines and their catabolites, their unexplored effects on nucleotide-gated and glutamate receptor channels of cell membranes and $\mathrm{Ca}^{2+}$-permeable and $\mathrm{K}^{+}$-selective channels in the membranes of plant mitochondria and chloroplasts, and pleiotropic mechanisms of polyamines' action on $\mathrm{H}^{+}$and $\mathrm{Ca}^{2+}$ pumps.

Keywords: abiotic stress, $\mathrm{Ca}^{2+}$ ATPase, $\mathrm{H}^{+}$-ATPase, ion channel, organelle, polyamines, TPC1, vacuole

\section{INTRODUCTION}

Polyamines (PAs) are plant growth regulators and important components of plant stress responses (Alcázar et al., 2010; Takahashi and Kakehi, 2010; Pottosin and Shabala, 2014; Pál et al., 2015; Paschalidis et al., 2019). PAs putrescine $e^{2+}$ (Put), spermidine ${ }^{3+}$ (Spd), and spermine ${ }^{4+}(\mathrm{Spm})$ are natural polycations and, therefore, can affect different cation transporters, including those regulating $\mathrm{Ca}^{2+}$ homeostasis and signaling (Pottosin and Shabala, 2014). Stress-induced PA changes can remodel ion transport across cellular membranes, with important consequences for plant performance (Pottosin and Shabala, 2014; Pottosin, 2015). PA effects on ion transport depend on cell-, tissue-, and genotype-specificity and growth conditions (Pandolfi et al., 2010). Most likely, PAs were not originally designed as signaling compounds but then acquired this function during evolution by leveraging on a strong variation of levels of individual PAs and their catabolites during plant responses to changing environment. Owing to this level of complexity, the initial 
question should be related to the primary effects of different PAs and their catabolites (e.g., ROS) on individual ion transporters. Are these effects direct and specific for different PAs? Are there allosteric PA-binding sites? In vivo effects may be also dependent on the PA metabolism and traffic, and an involvement of the intermediate signaling. Finally, catabolization of PAs and signaling by their catabolites, ROS and GABA, should be considered. The aim of this work is to elucidate diverse effects of PAs on key plant membrane ion transporters to stimulate more focused studies in this field.

\section{POLYAMINE TRANSPORT MAY AFFECT MEMBRANE POTENTIAL AND $\triangle \mathrm{pH}$}

Polyamines induce a rapid depolarization in roots and leaves (Fromm et al., 1997; Ozawa et al., 2010; Pottosin et al., 2014a). A significant part of it is due to the traffic per se of these polycations across the plasma membrane, PM (Pottosin et al., 2014a). Interestingly, PM Put transporter, PUT3, is phosphorylated by SOS2 (CIPK24). It forms a tertiary complex with SOS1 (PM Na${ }^{+} / \mathrm{H}^{+}$antiporter) and SOS2, key elements in response to salinity; within this complex, the activity of PUT3 and SOS1 is synergistically modulated (Chai et al., 2020). Thus, Put uptake can contribute to the $\mathrm{pH}$ and $\mathrm{Na}^{+}$regulation. PA traffic is documented for most intracellular membranes, albeit transporters, which facilitate PA uptake into plant vacuoles and mitochondria, remain elusive (Fujita and Shinozaki, 2015). No specific PA transporter was postulated for chloroplasts, but chloroplasts represent the main source of Put synthesis in photosynthetic tissues (Borrell et al., 1995). In Arabidopsis chloroplasts, Put may account for up to $40 \%$ of the total cellular Put (Krueger et al., 2011). A small but significant fraction of unprotonated (uncharged) Put can freely diffuse through the thylakoid membrane and partly buffer the light-induced thylakoid lumen acidification, changing the proportion between membrane potential $(\Delta \Psi)$ and $\Delta \mathrm{pH}$ across the thylakoid membrane (Ioannidis et al., 2006, 2012). Under salinity, Putinduced increase in $\Delta \Psi$ at the expense of $\Delta \mathrm{pH}$ stimulates cyclic electron flow and decreases $\mathrm{pH}$-dependent non-photochemical quenching. This increases the quantum yield by PSII, decreasing the overreduction of PSI acceptors and, eventually, enhancing the ATP production (Wu X. et al., 2019). A stark increase in the Put production upon $\mathrm{K}^{+}$deficiency is accompanied by an increase in the $\mathrm{Mg}^{2+}$ content. $\mathrm{Mg}^{2+}$ uptake into thylakoids causes an opposite effect on $\Delta \Psi / \Delta \mathrm{pH}$ partition and favors lumen acidification and stromal alkalinization, optimal for the Calvin cycle (Cui et al., 2020).

\section{DIRECT EFFECTS OF POLYAMINES ON THE TONOPLAST CATION CHANNELS}

Tonoplast harbors two types of cation channels: slow (SV/TPC1) and fast (FV) vacuolar channels. FV channels are inhibited by micromolar $\mathrm{Ca}^{2+}$ and $\mathrm{Mg}^{2+}$ and conduct small monovalent cations indiscriminately, whereas SV channels are activated by an elevated cytosolic $\mathrm{Ca}^{2+}$ and conduct both monovalent and divalent cations with a little preference (Pottosin and Dobrovinskaya, 2014, 2018). Both channels are rapidly, reversibly, and directly suppressed by PAs (Pottosin and Shabala, 2014; Table 1). PAs cause the voltage-dependent block of the SV/TPC1 pore. In agreement with an early study (Colombo et al., 1992), PAs can be transported by SV/TPC1. The FV current is intrinsically flickering, and its inhibition by cytosolic PAs is voltage independent. It remains to be elucidated whether PAs block the FV channel or alter its gating.

In silico analysis predicts two binding sites for Put within the TPC1 pore, one below and one above the filter (Figure 1, bottom left), in agreement with a multioccupancy block by this diamine (Pottosin, 2015). These sites overlap with the conducting route for permeable cations, implying their mutual competition. Longer Spm and Spd molecules partly share the external binding site with Put (Figure 1, bottom right), but their binding is much stronger. An additional binding site for Spm was predicted in the TPC1 cytosolic domain, overlapping with the regulatory $\mathrm{Ca}^{2+}$-binding site (Figure 1, top).

A suppression of the FV and SV channels by PAs is essential at any condition but is more important under salinity. FV and SV channels are unable to differentiate between $\mathrm{K}^{+}$and $\mathrm{Na}^{+}$, thus mediating the $\mathrm{Na}^{+}$leak from the vacuole (Pottosin and Dobrovinskaya, 2014). A futile vacuolar $\mathrm{Na}^{+}$cycling has a rather high energy cost, imposing a penalty for plant performance (Shabala et al., 2020). The suppression of vacuolar FV and SV channels may also be relevant at conditions of $\mathrm{K}^{+}$deprivation, preventing vacuolar reuptake of cytosolic $\mathrm{K}^{+}$by $\mathrm{FV}$ and $\mathrm{SV}$ channels. Notably, the overexpression of the tonoplast $\mathrm{K}^{+}\left(\mathrm{Na}^{+}\right) / \mathrm{H}^{+}$antiporter $\mathrm{NHX} 1$, which mediates vacuolar $\mathrm{K}^{+}$uptake, may be counterbalanced by a massive increase in Put under $\mathrm{K}^{+}$deprivation (De Luca et al., 2018).

\section{INDIRECT EFFECTS OF POLYAMINES ON THE PLASMA MEMBRANE $\mathrm{K}^{+}$ CHANNELS}

In animal systems, PAs act as direct pore-plugging agents, underlying inward rectification of $\mathrm{K}^{+}$-selective Kir channels and exerting a voltage-dependent block of a variety of cation channels, including $\mathrm{Na}^{+}$(lacking in plants) and ligand-gated channels (Williams, 1997; Guo and Lu, 2000; Huang and Moczydlowski, 2001). Cyclic nucleotides-gated and glutamate receptor channels in animal cells are blocked by PAs with a high affinity in a charge-specific manner. No data are available for their homologs, abundant in plants.

Plant voltage-dependent $\mathrm{K}^{+}$channels belong to the Shaker family (Sharma et al., 2013). Their counterparts in animal cells are not blocked by the physiological concentrations of PAs. Inward rectifying $\mathrm{K}^{+}$channels in guard cells are suppressed by endogenous PAs, which promote stomata closure under drought 
TABLE 1 | Key plant plasma membrane and vacuolar ion transporters - targets for polyamines.

\begin{tabular}{lll}
\hline Ion transporter & Ionic transport & Involvement in stress responses \\
& function/physiological & PA effect (half-efficient \\
implications & concentration)
\end{tabular}

Slow vacuolar SV channel (TPC1) Transport of $\mathrm{Ca}^{2+}, \mathrm{Na}^{+}, \mathrm{Mg}^{2+} \mathrm{K}^{+}$, $\mathrm{NH}_{4}{ }^{+}$, and other small cations across tonoplast ${ }^{(1)}$, vacuolar $\mathrm{K}^{+}$ release/cytoplasmic $\mathrm{K}^{+}$ homeostasis ${ }^{(2)}, \mathrm{Ca}^{2+}$ - and voltage-induced vacuole electrical excitability/intracellular signaling

$(3,4), \mathrm{Ca}^{2+}$ release and

long-distance signaling/sensors and amplifiers of $\mathrm{Ca}^{2+}$ signal, $\mathrm{ROS}$, and $\mathrm{Ca}^{2+}$ interplay ${ }^{(3,5-7)}$, cation homeostasis ${ }^{(8,9)}$, ABA signaling in seed germination and stomatal closure $(10,11)$

Fast vacuolar FV channel (unknown molecular identity)

Vacuolar $\mathrm{K}^{+}$VK channel (TPK1)

Inward-rectifying shaker $\mathrm{K}^{+}$ channels (AKT1, KAT1)

Outward-rectifying shaker $\mathrm{K}^{+}$ Channels (SKOR, GORK)

Voltage-independent non-selective cation channels VI-NSCC (uncertain molecular identity)

Reactive oxygen species-induced $\mathrm{Ca}^{2+}$ influx ROSIC

Weakly voltage-dependent, $\mathrm{OH} \bullet$-induced non-selective conductance (unknown molecular identity)
$\mathrm{NH}_{4}{ }^{+}>\mathrm{K}^{+}>\mathrm{Na}^{+}$transport (22), $\mathrm{K}^{+}$uptake and release/Volume adjustment via auxin (23), tonoplast electric potential regulation ${ }^{(24)}, \mathrm{K}^{+}$ sensing/intracellular $\mathrm{K}^{+}$ homeostasis ${ }^{(25)}$, vacuolar volume adjustment via auxin (26)

Selective $\mathrm{K}^{+}$transport across tonoplast $(30-33), \mathrm{K}^{+}$homeostasis, vacuolar $\mathrm{K}^{+}$mobilization, stomata closure ${ }^{(34-36)}$, mechano- and osmo-sensor ${ }^{(37)}$, vacuolar excitability in combination with $\mathrm{TPC}^{(4)}$

$\mathrm{K}^{+}$uptake and tissue $\mathrm{K}^{+}$ transport ${ }^{(33,40-44)}$ and stomata opening $(45,46)$

$\mathrm{K}^{+}$efflux, general metabolic switch, cell death ${ }^{(33,56,57)}, \mathrm{K}^{+}$loading into xylem, SKOR $(43,44,58)$, stomata closure, GORK $(59,60)$, initial depolarization phase of the action potentials ${ }^{(61)}$

General cation transport/uptake of nutrients, growth and development, $\mathrm{Ca}^{2+}$ influx/transduction of stimuli (cyclic nucleotides, membrane stretch, amino acids, and purines) $(1,68)$

Non-selective cation and small anions conductance ${ }^{(74-77)}, \mathrm{Ca}^{2+}$ influx and signaling via ROS and ABA/stomatal closure $(75,76,78)$, polarized (root hair, pollen tube) $\operatorname{growth}^{(74,79)}$
Salt stress (detrimental vacuolar $\mathrm{Na}^{+}$leak) $(3,5,7,12-14)$, long-distance signaling (5), aluminum tolerance ${ }^{(15)}$, lead stress response ${ }^{(16)}$, wounding via jasmonate signaling ${ }^{(17)}$, insect herbivory response ${ }^{(6)}$, hypoxia sensors (18)

Detrimental for salt stress (vacuolar $\mathrm{Na}^{+}$leak) ${ }^{(13,24,27)}, \mathrm{K}^{+}$deprivation (vacuolar $\mathrm{K}^{+}$-cycling) $(25,28)$

Salt stress $(31,33,38)$ and $\mathrm{K}^{+}$ deprivation $(28,34,36)$, tolerance by refilling of cytosolic $\mathrm{K}^{+}$

$\mathrm{K}^{+}$starvation/deficiency, $\mathrm{K}^{+}$ uptake $^{(33,47,48)}, \mathrm{Fe}^{2+}$ toxicity tolerance ${ }^{(49)}$, drought tolerance by enhancing root $\mathrm{K}^{+}$uptake $(42,50,51)$

Salt stress (sensitivity via $\mathrm{K}^{+}$loss) $(43,57,58,62,63)$, cell death ${ }^{(64)}$, relocation of energy from metabolism to defense ${ }^{(56)}$, oxidative stress tolerance by cation distribution (65)

Salt stress sensitivity, $\mathrm{Na}^{+}$ influx ${ }^{(1,68-71)}$

Drought stress, signaling(78), salinity ${ }^{(64)}$, hypersensitive response to biotic stress ${ }^{(80)}$
Direct, reversible. Voltage-dependent block from either membrane side $\left(\mathrm{Spm}^{4+}\right.$ $50 \mu \mathrm{M}>\mathrm{Spd}^{3+} 500 \mu \mathrm{M}>\mathrm{Put}^{2+}$ $3 \mathrm{mM})^{(19-21)}$
Direct, reversible, voltage-independent, from the cytosolic side $\left(\mathrm{Spm}^{4+}\right.$ $6 \mu \mathrm{M}>\mathrm{Spd}^{3+} 80 \mu \mathrm{M}>>\mathrm{Put}^{2+}$ $4 \mathrm{mM})(19,21,29)$

Voltage-independent, cytosolic side block $\left(\mathrm{Spm}^{4+} \sim \mathrm{Spd}^{3+}\right.$ $0.5 \mathrm{mM})^{(39)}$
Indirect inhibition, cytosolic side (52), indirect, extracellular side ${ }^{(53,54)}$, voltage-independent $\mathrm{Spm}^{4+} \sim \mathrm{Spd}^{3+} \sim \mathrm{Put}^{2+}$ $0.5-1 \mathrm{mM})$, inhibition via increase in $\mathrm{PIP}_{2}$ (55)

Indirect inhibition from extracellular side, voltage-independent $\left(\mathrm{Spm}^{4+}\right.$ $\left.\sim \mathrm{Put}^{2+} 1 \mathrm{mM}\right)^{(54)}$, activation from extracellular side via increase in $\mathrm{PIP}_{2}$ and PLD $\delta$ activity $\left(\mathrm{Spm}^{4+}=\mathrm{tSpm}^{4+}>\mathrm{Spd}^{3+}>\right.$ $\left.>\mathrm{Put}^{2+} \approx \mathrm{Dap}^{2+}\right)^{(66,67)}, \mathrm{GABA}$ formed by $\mathrm{Put}^{2+}$ catabolism decreases the expression (63)

Extracellular side, voltage-independent inhibition $\mathrm{SSpm}^{4+} \sim \mathrm{Spd}^{3+}$

$(\sim 1 \mathrm{mM})>$ Put $\left.^{2+}\right)^{(53)}$, extracellular side, indirect? $\left(\mathrm{Spm}^{4+} \sim \mathrm{Spd}^{3+} \sim\right.$ $\left.\mathrm{Put}^{2+} 1 \mathrm{mM}\right)$ (72.73)

Extracellular PAs act as cofactors for ROSIC activation by $\mathrm{OH}\left(\mathrm{Spm}^{4+}\right.$ $\left.\sim \mathrm{Spd}^{3+} \sim \mathrm{Put}^{2+} 1 \mathrm{mM}\right)^{(75,81,82)}$, PA export and oxidation by DAO or $\mathrm{PAO}$ results in the ROS burst in the apoplast and activation of $\mathrm{Ca}^{2+}$ influx via ROSIC upon pathogen attack (83-85), salinity ${ }^{(86)}$, ABA-induced stomata closure (87) 
TABLE 1 | Continued

\begin{tabular}{|c|c|c|c|}
\hline Ion transporter & $\begin{array}{l}\text { lonic transport } \\
\text { function/physiological } \\
\text { implications }\end{array}$ & Involvement in stress responses & $\begin{array}{l}\text { PA effect (half-efficient } \\
\text { concentration) }\end{array}$ \\
\hline $\begin{array}{l}\mathrm{H}^{+} \text {-pump } \\
\text { P-type ATPase } \\
\text { (AHA: auto inhibited } \mathrm{H}^{+} \text {-ATPAse) }\end{array}$ & $\begin{array}{l}\text { Drives } \mathrm{H}^{+} \text {extrusion and } \mathrm{PM} \\
\text { hyperpolarization }(88,89) \\
\text { intracellular and apoplastic } \mathrm{pH} \\
\text { regulation }(90-94) \text {, fueling } \\
\mathrm{H}^{+} \text {-coupled secondary transports } \\
(95-97), \text { plant growth and } \\
\text { development, stomatal } \\
\text { aperture }\end{array}$ & $\begin{array}{l}\text { Salt stress, generation of electric } \\
\text { and } \mathrm{pH} \text { gradients for } \mathrm{K}^{+} \text {uptake } \\
(43,62,102-105), \mathrm{Al}^{3+} \\
\text { toxicity/tolerance }{ }^{(106,107)} \text {, } \\
\text { pathogen infection sensitivity }{ }^{(97)} \text {, } \\
\text { alkaline stress tolerance }(108,109) \\
\text { drought adaptation by auxin }{ }^{(110)} \text {, } \\
\text { wounding, leaf-to-leaf electrical } \\
\text { signaling and plant defense }{ }^{(111)}\end{array}$ & 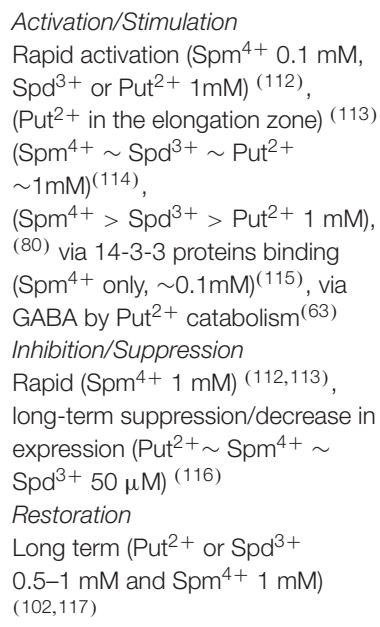 \\
\hline $\begin{array}{l}\mathrm{Ca}^{2+} \text {-pump } \\
\text { P-type ATPase } \\
\text { PMCA (the plasma membrane } \\
\text { located } \mathrm{Ca}^{2+} \text {-ATPases) } \\
\text { Type IIB (ACA: auto-inhibited } \\
\mathrm{Ca}^{2+} \text {-ATPase) }\end{array}$ & $\begin{array}{l}\mathrm{Ca}^{2+} \text { extrusion from cytosol, } \mathrm{Ca}^{2+} \\
\text { signaling, protein glycosylation, } \\
\text { protein and polysaccharide } \\
\text { secretion, enzymes activation, } \\
\text { stomatal closure }{ }^{(118-123)}, \text { plant } \\
\text { growth and development }(124-126)\end{array}$ & $\begin{array}{l}\text { Abiotic stresses }{ }^{(118,127)}, \mathrm{Ca}^{2+} \\
\text { stress (deficiency) }^{(128)} \text {, salinity } \\
\text { adaptation }^{(118,119)} \text {, chilling }{ }^{(129)} \text {, } \\
\text { anoxia }^{(118)}, \mathrm{Mn}^{2+} \text { toxicity }{ }^{(119)} \text {, } \\
\text { pathogen-induced cell death and } \\
\text { signaling }{ }^{(130)}\end{array}$ & $\begin{array}{l}\text { Rapid activation }\left(\mathrm{Spm}^{4+} \sim \mathrm{Put}^{2+}\right. \\
0.1-1 \mathrm{mM})(75,81,82,119) \text { and } \\
\text { long-term potentiation via } \mathrm{Spm}^{4+} \text {, } \\
\text { Spd }^{3+} \text {, or Put }{ }^{2+} \text { production by } \\
\text { salicylic acid }\end{array}$ \\
\hline
\end{tabular}

${ }^{1}$ Pottosin and Dobrovinskaya, 2014; ${ }^{2}$ Hedrich et al., 2018; ${ }^{3}$ Pottosin and Dobrovinskaya, 2018; ${ }^{4}$ Jaślan et al., $2019 ;{ }^{5}$ Choi et al., $2014 ;{ }^{6}$ Kiep et al., $2015 ;{ }^{7}$ Evans et al., 2016; ${ }^{8}$ Hedrich and Marten, 2011; ${ }^{9}$ Hedrich et al., 2018; ${ }^{10}$ Peiter et al., 2005; ${ }^{11}$ Peiter, 2011; ${ }^{12}$ Bonales-Alatorre et al., 2013 ; ${ }^{13}$ Shabala et al., 2020 ; ${ }^{14}$ Koselski et al., 2019; ${ }^{15}$ Wherrett et al., 2005; ${ }^{16}$ Miśkiewicz et al., 2020; ${ }^{17}$ Lenglet et al., 2017; ${ }^{18}$ Wang et al., 2017 ; ${ }^{19}$ Dobrovinskaya et al., 1999 b; ${ }^{20}$ Dobrovinskaya et al., $1999 a ;$ ${ }^{21}$ Pottosin and Shabala, 2014; ${ }^{22}$ Brüggemann et al., 1999; ${ }^{3}$ Burdach et al., 2020; ${ }^{24}$ Tikhonova et al., 1997; ${ }^{25}$ Pottosin and Martínez-Estévez, 2003; ${ }^{26}$ Burdach et al., 2018; ${ }^{27}$ Pottosin and Muñiz, 2002; ${ }^{28}$ Cui et al., 2020; ${ }^{29}$ Brüggemann et al., 1998; ${ }^{30}$ Ward and Schroeder, $1994 ;{ }^{31}$ Pottosin et al., $2003 ;{ }^{32}$ Bihler et al., 2005; ${ }^{33}$ Chérel and Gaillard, 2019; ${ }^{34}$ Gobert et al., 2007; ${ }^{35}$ Ragel et al., 2019; ${ }^{36}$ Tang et al., 2020; ${ }^{37}$ Maathuis, 2011; ${ }^{38}$ Wang et al., 2013; ${ }^{39}$ Hamamoto et al., 2008; 40 Dreyer et al., 2017; ${ }^{41}$ Chen et al., 2017; ${ }^{42}$ Feng et al., 2020; ${ }^{43}$ Rubio et al., 2020; ${ }^{44}$ Raddatz et al., 2020; ${ }^{45}$ Kwak et al., $2001 ;{ }^{46}$ Wang Y. et al., 2018; ${ }^{47}$ Wang and Wu, 2013; ${ }^{48}$ Zhang et al., 2018; ${ }^{49}$ Wu L. B. et al., 2019; ${ }^{50}$ Shabala and Cuin, 2008; ${ }^{51}$ Ahmad et al., 2016; 52 Liu et al., $2000 ;{ }^{53}$ Zhao et al., $2007 ;{ }^{54}$ Pottosin, 2015; ${ }^{55}$ Xie et al., 2005; ${ }^{56}$ Demidchik, 2014; ${ }^{57}$ Adem et al., 2020; ${ }^{58}$ Gaymard et al., 1998; ${ }^{59}$ Hosy et al., 2003; ${ }^{60}$ Corratgé-Faillie et al., 2017 ; ${ }^{61}$ Cuin et al., $2018 ;{ }^{62}$ Buch-Pedersen et al., 2006, ${ }^{63}$ Su et al., 2019; ${ }^{4}$ Demidchik et al., 2010; ${ }^{65}$ Garcia-Mata et al., 2010; 66 Zarza et al., 2019; 67 Zarza et al., $2020 ;{ }^{68}$ Demidchik and Maathuis, 2007; ${ }^{69}$ Demidchik and Tester, 2002; ${ }^{70}$ Essah et al., 2003; ${ }^{71}$ Keisham et al., 2018; ${ }^{72}$ Shabala et al., 2007a; ${ }^{73}$ Shabala et al., 2007 b; ${ }^{74}$ Foreman et al., 2003 ; ${ }^{75}$ Zepeda-Jazo et al., 2011 ;

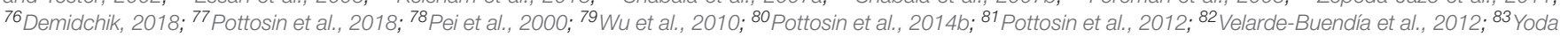

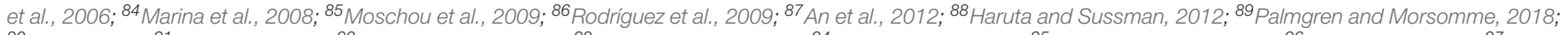

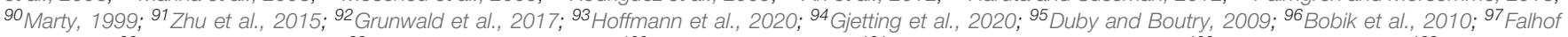

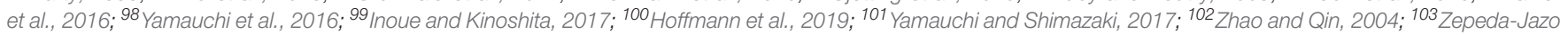

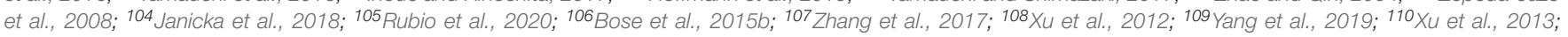

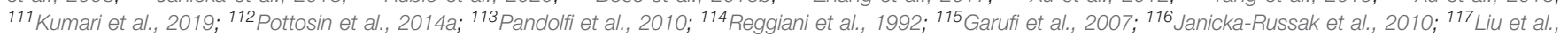

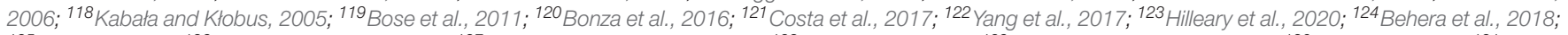

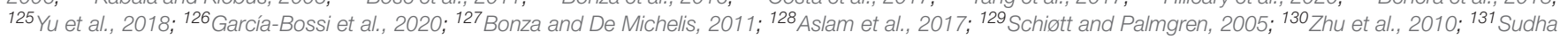
and Ravishankar, 2003.

(Liu et al., 2000). An indirect inhibition was also reported for both inward- and outward-rectifying Shaker $\mathrm{K}^{+}$channels in roots (Table 1). Membrane-bound $\mathrm{PIP}_{2}$ is a cofactor for numerous $\mathrm{PM}$ cation channels in animals (Suh and Hille, 2008) and inwardand outward-rectifying Shaker $\mathrm{K}^{+}$channels in plants (Liu et al., 2005). PAs block animal inward rectifier Kir2.1 but also activate it by strengthening the interaction with $\mathrm{PIP}_{2}$ (Xie et al., 2005). PAs induced a rapid increase in $\mathrm{PIP}_{2}$ in Arabidopsis seedling, triggering a massive $\mathrm{K}^{+}$efflux mediated by outward-rectifying GORK channels (Zarza et al., 2020). This mechanism appears to be specific for Arabidopsis. In vivo studies on pea and barley roots did not reveal any significant Spm-induced $\mathrm{K}^{+}$efflux (ZepedaJazo et al., 2011; Velarde-Buendía et al., 2012).

\section{PLEIOTROPIC EFFECTS OF POLYAMINES ON $\mathrm{H}^{+}$AND $\mathrm{Ca}^{2+}$ PUMPS}

Operation of the PM-based $\mathrm{H}^{+}$- and $\mathrm{Ca}^{2+}$-ATPase pumps is central for responses to a variety of biotic and abiotic stresses (Table 1). An abrupt activation of $\mathrm{H}^{+}$pumping occurs upon salt and hypertonic shock (Shabala and Cuin, 2008; Pandolfi et al., 2010; Bose et al., 2015a).

Upon long-term exposures, free and conjugated PAs could modify (either activate or inhibit) the activity of the $\mathrm{PM} \mathrm{H}^{+}$- and $\mathrm{Ca}^{2+}$-ATPase pumps. This may be due to the changes in the protein expression, membrane composition/stability, and redox state 


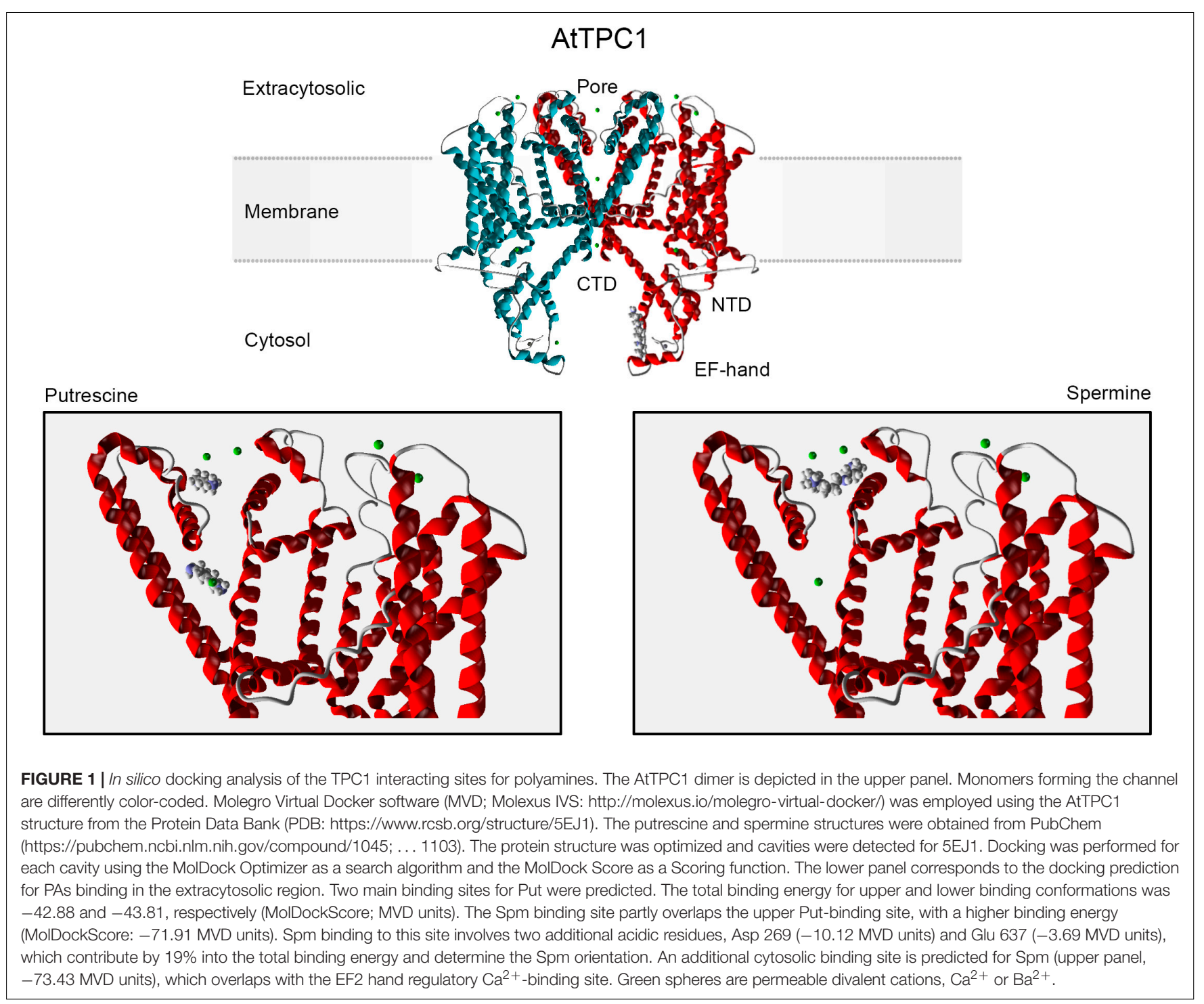

(Srivastava and Rajbabu, 1983; Sudha and Ravishankar, 2003; Liu et al., 2005, 2014; Roy et al., 2005; Janicka-Russak et al., 2010; Du et al., 2015). Tonoplast $\mathrm{H}^{+}$pumps, V-type ATPase and PPase, are only slightly affected by PAs, both upon direct application (Liu et al., 2004, 2006; Zhao and Qin, 2004) and after long-term exposure (Sun et al., 2002; Tang and Newton, 2005). Plant mitochondrial F-ATPase showed low sensitivity to PAs at physiological ionic conditions (Peter et al., 1981).

In pea and barley roots, PAs indiscriminately (Put $\sim \mathrm{Spm}$ ) induced eosin-sensitive $\mathrm{Ca}^{2+}$ efflux, pinpointing to the $\mathrm{Ca}^{2+}$ ATPase activation (Zepeda-Jazo et al., 2011; Velarde-Buendía et al., 2012; Pottosin et al., 2014b). Low millimolar concentrations of PAs stimulated the $\mathrm{PM} \mathrm{H}^{+}$-ATPase activity in rice coleoptiles, but only Put can reach this concentration in planta (Reggiani et al., 1992). Spm and Spd caused a transient increase in a vanadate-sensitive $\mathrm{H}^{+}$pumping in pea roots, whereas Put induced a sustained $\mathrm{H}^{+}$efflux (Pottosin et al., 2014a). The general mechanism of the $\mathrm{PM} \mathrm{H}^{+}$-ATPase activation involves a phosphorylation of a penultimate Thr, which promotes 143-3 protein binding and relief of the autoinhibition, while phosphorylation of other Ser and Thr residues in the C-terminal may either activate or inhibit the $\mathrm{H}^{+}$-ATPase (Falhof et al., 2016). $\mathrm{Ca}^{2+}$-dependent phosphorylation of Ser931 by SOS2like kinase prevents the 14-3-3 protein binding, thus inhibiting the $\mathrm{PM} \mathrm{H}^{+}$-ATPase (Fuglsang et al., 2007). PA-induced $\mathrm{Ca}^{2+}{ }_{-}$ efflux may indirectly activate the $\mathrm{H}^{+}$-pumping in vivo by the local cytosolic $\mathrm{Ca}^{2+}$ depletion. Indeed, Put-induced stimulation of $\mathrm{H}^{+}$pumping was suppressed by the $\mathrm{Ca}^{2+}$-pump inhibition, whereas Put did not affect the $\mathrm{PM} \mathrm{\textrm {H } ^ { + }}$-pump in vitro. In addition, cytosolic Spm at higher concentration inhibited the $\mathrm{H}^{+}$pumping by pea root PM vesicles (Pottosin et al., 2014a). Spm but not Spd or Put suppressed the $\mathrm{H}^{+}$pumping in maize roots (Pandolfi et al., 2010). Contrary to this, Spm but no other PAs stimulated the $\mathrm{PM} \mathrm{H}^{+}$-ATPase activity both in maize and Arabidopsis by a promotion of the 14-3-3 protein binding to the unphosphorylated C-terminal (Garufi et al., 2007). 
However, $\mathrm{H}^{+}$efflux and $\mathrm{H}^{+}$-ATPase activity are not necessarily correlated. In its upregulated state, the $\mathrm{PM} \mathrm{H}^{+}$-ATPase transports $1 \mathrm{H}^{+}$per 1 ATP, but this coupling may be loosened at high cytosolic cation concentration (Buch-Pedersen et al., 2006). Whether Spm may act as such an uncoupler remains to be elucidated. Also, Spm and Spd but not Put are able to compete with $\mathrm{Mg}^{2+}$ for binding to ATP, thus decreasing the ATPase activity, e.g., of a mitochondrial F-type ATPase (Igarashi et al., 1989). As $\mathrm{Mg}^{2+}$ and Spm binding sites in ATP are overlapped only partly, a ternary complex ATP- $\mathrm{Mg}^{2+}$-Spm can be formed, which is processed by an ATPase more rapidly than Mg-ATP (Meksuriyen et al., 1998).

\section{EFFECTS OF POLYAMINE CATABOLITES: ROS AND GABA}

A substantial part of PA effects may be attributed to their catabolites, and the balance of the PA synthesis and catabolization is stress-regulated and may define the net response (Moschou et al., 2012; Pottosin et al., 2014b; Pál et al., 2015; Gupta et al., 2016). The immediate product of PA oxidation by diamine(DAO; for Put) and polyamine- (PAO; for Spm and Spd) oxidases is $\mathrm{H}_{2} \mathrm{O}_{2}$. It could be converted to a more aggressive hydroxyl radical $\left(\mathrm{OH}^{\bullet}\right)$ in the presence of the transition metals in the cell wall (Demidchik, 2014) and cytosol (Rodrigo-Moreno et al., 2013). These two ROS species target two types of conductances: (1) non-selective $\left(\mathrm{Ca}^{2+}\right.$-permeable) also known as ROS-activated NSCC or ROSIC (Pei et al., 2000; Demidchik and Maathuis, 2007; Zepeda-Jazo et al., 2011) and (2) outward-rectifying $\mathrm{K}^{+}$selective channels GORK and SKOR (Demidchik et al., 2010; Garcia-Mata et al., 2010). ROS generation upon PA catabolization in the apoplast is essential for the hypersensitive response to pathogen attack, wound-healing, stomata closure, and salinityassociated ROS signaling, among all (see Tavladoraki et al., 2012; Pottosin et al., 2014b). The source depends on the relative expression of amine oxidases: mainly DAO in dicots and mainly PAO in monocots (Moschou et al., 2008). Transmission of the external ROS signal to internal signaling is mediated by ROSactivated $\mathrm{Ca}^{2+}$ influx, positively fed back to ROS production due to a $\mathrm{Ca}^{2+}$ activation of the PM-bound NADPH-dehydrogenase (Takeda et al., 2008; Demidchik et al., 2018; Pottosin and Zepeda-Jazo, 2018). In pea roots, $\mathrm{OH}^{\bullet}$ at lower and higher levels, respectively, induced a transient $\mathrm{Ca}^{2+}$ pumping by $\mathrm{Ca}^{2+}$. ATPase and a sustained $\mathrm{Ca}^{2+}$ influx via ROSIC (Zepeda-Jazo et al., 2011). $\mathrm{OH}^{\bullet}$-induced $\mathrm{Ca}^{2+}$ pumping was potentiated by PAs, with $\mathrm{Ca}^{2+}$ efflux becoming sustained in pea roots in the presence of Spm (Zepeda-Jazo et al., 2011; Pottosin et al., 2012), whereas in barley, the $\mathrm{OH}^{\bullet}$ and PA effects on $\mathrm{Ca}^{2+}$ pumping were roughly additive (Velarde-Buendía et al., 2012). PAs also potentiated the ROSIC-mediated $\mathrm{K}^{+}$efflux (Zepeda-Jazo et al., 2011). This potentiation was much more pronounced in a salt-tolerant vs. salt-sensitive barley variety (Velarde-Buendía et al., 2012). In cereals such as barley and wheat, the magnitude of the ROS-induced $\mathrm{K}^{+}$efflux correlates negatively with salt tolerance (Maksimović et al., 2013; Wang W. et al., 2018). However, ROS-induced $\mathrm{K}^{+}$efflux by modified GORK channels can also result in a "metabolic switch" relocating more cell energy to stress defense (Demidchik, 2014; Shabala, 2017). A transient drop in the cytosolic $\mathrm{K}^{+}$in a local region (e.g., root tip) per se could also serve as a stress signal (Shabala, 2017).

The $\gamma$-aminobutyric acid (GABA) in plants is produced via decarboxylation of glutamate or by a two-step Put catabolization. Increased DAO expression in response to abiotic stresses (Shelp et al., 2012) may lead to increased GABA production. Upon heavy metal and hypoxia, GABA production is fed back, promoting the PA biosynthesis and reducing their catabolization (Wang et al., 2014; Seifikalhor et al., 2020). GABA inhibits the malate efflux from roots by a direct binding to anion transporter ALMT1 (Ramesh et al., 2015). GORK contains a conserved GABAbinding motif, and GABA induces $\mathrm{K}^{+}$efflux via GORK (Adem et al., 2020). GABA over-accumulating Arabidopsis mutant displayed increased activity of the $\mathrm{PM} \mathrm{H}^{+}$ATPase, a better control of the membrane potential and $\mathrm{K}^{+}$retention/reduced ROS-induced $\mathrm{K}^{+}$efflux from roots, and lower $\mathrm{Na}^{+}$uptake, conferring salt tolerance ( $\mathrm{Su}$ et al., 2019). GABA provokes a hyperpolarization, via either inhibition of anion efflux via ALMT or stimulation of the $\mathrm{H}^{+}$pumping; it reduces $\mathrm{ROS}$-induced $\mathrm{K}^{+}$ efflux but increases ROS-induced $\mathrm{Ca}^{2+}$ efflux from barley roots (Shabala et al., 2014; Gilliham and Tyerman, 2016). Thus, GABA may antagonize the effects of ROS overproduction under stresses, which increase $\mathrm{K}^{+}$efflux and $\mathrm{Ca}^{2+}$ uptake.

Polyamines and their catabolism also rapidly upturn NO signaling, which targets multiple ion transporters. These include activation of the $\mathrm{PM} \mathrm{H}^{+}$-ATPase, inhibition (by direct nitrosylation) of GORK channels, activation of $\mathrm{Ca}^{2+}$ influx across the $\mathrm{PM}$, and $\mathrm{Ca}^{2+}$ release from intracellular stores. The latter could lead to $\mathrm{Ca}^{2+}$-dependent activation of the slow anion and inhibition of inward-rectifying $\mathrm{K}^{+}$currents, provoking stomata closure (Pottosin and Shabala, 2014; Seifikalhor et al., 2019).

\section{OUTLOOK}

In contrast to $\mathrm{Ca}^{2+}$ and $\mathrm{Mg}^{2+}$, which act at a point, PAs with repeatedly space-distributed charges can form links between multiple binding anionic centers, which explains a higher binding affinity for longer polyamines in comparison to diamine Put, predicted by the docking analysis. Respective amino acids should be mutated to test whether they decrease the affinity of block by PAs and, if so, to verify whether this will be detrimental for plants' performance under stress (e.g., salinity). In addition to pore block, long PA Spm likely interferes with cytosolic $\mathrm{Ca}^{2+}$ binding to the EF2 site (Figure 1). EF2 is critical for the AtTPC1 activation (Guo et al., 2016), whereas $\mathrm{Ca}^{2+}$ binding to EF1 likely has an allosteric effect, increasing $\mathrm{Ca}^{2+}$ affinity for EF2 (Demidchik et al., 2018). Spm binding along the EF2 loop would affect its mobility and $\mathrm{Ca}^{2+}$ affinity, thus potentially altering TPC1 gating.

There are several unresolved problems regarding PA effects on PM ion transporters. In plants, PAs affect two key PM ionotropic ATPases, $\mathrm{Ca}^{2+}$ and $\mathrm{H}^{+}$pumps. Diverse and sometimes opposite effects on the $\mathrm{H}^{+}$-ATPase imply multiple and mostly indirect mechanisms. A rapid stimulation of $\mathrm{Ca}^{2+}$ pumping by PAs in barley and pea roots is worth to be explored in other plant species and in vitro studies with isolated $\mathrm{Ca}^{2+}$-ATPases. By analogy 
with their animal counterparts, glutamate receptors and cyclic nucleotide gated channels are plausible but unexplored targets for PAs in plants. In the latter case, in addition to direct effects, the signaling cascade involving PA catabolization-NO generationactivation of the adenylate cyclase- $\mathrm{Ca}^{2+}$ signal is worth to be explored (Jeandroz et al., 2013; Pottosin and Shabala, 2014). Overall, signaling by PAs needs to be considered in a close context with ROS, $\mathrm{NO}$, and $\mathrm{Ca}^{2+}$ signaling.

Direct effects of free and conjugated PAs on individual ion transporters should be compared, and underexplored effects of cadaverine and thermospermine should be addressed. Also, our knowledge on PA traffic and subcellular compartmentalization remains fragmentary. Early studies suggested that the vacuolar PA concentration is lower than that in the cytosol (Pistocchi et al., 1987; DiTomaso et al., 1992). Taking into the account the dominant vacuolar volume, it implies that if one operates with an average tissue PA content, actual cytosolic and vacuolar PA concentrations are several times under- and overestimated, respectively.

Polyamines alleviate stress-induced suppression of photosynthesis in different ways, including a stabilization of the thylakoid ultrastructure, control of lipid composition, regulation of the expression, structure and oligomerization of photosynthetic membrane proteins, promotion of the chlorophyll biosynthesis, and improvement of the antioxidant activity (Hamdani et al., 2011; Hu et al., 2014; Li et al., 2015, 2018; Shu et al., 2015). However, to the best of our knowledge,

\section{REFERENCES}

Adem, G. D., Chen, G., Shabala, L., Chen, Z. H., and Shabala, S. (2020). GORK channel: a master switch of plant metabolism? Trends Plant Sci. 25, 434-445. doi: 10.1016/j.tplants.2019.12.012

Ahmad, I., Mian, A., and Maathuis, F. J. M. (2016). Overexpression of the rice AKT1 potassium channel affects potassium nutrition and rice drought tolerance. J. Exp. Bot. 67, 2689-2698. doi: 10.1093/jxb/erw103

Alcázar, R., Altabella, T., Marco, F., Bortolotti, C., Reymond, M., Koncz, C., et al. (2010). Polyamines: molecules with regulatory functions in plant abiotic stress tolerance. Planta 231, 1237-1249. doi: 10.1007/s00425-010-1130-0

An, Z. F., Li, C. Y., Zhang, L. X., and Alva, A. K. (2012). Role of polyamines and phospholipase D in maize (Zea mays L.) response to drought stress. S. Afr. J. Bot. 83, 145-150. doi: 10.1016/j.sajb.2012.08.009

Aslam, R., Williams, L. E., Bhatti, M. F., and Virk, N. (2017). Genome-wide analysis of wheat calcium ATPases and potential role of selected ACAs and ECAs in calcium stress. BMC. Plant Biol. 17:174. doi: 10.1186/s12870-017-1112-5

Behera, S., Zhaolong, X., Luoni, L., Bonza, M. C., Doccula, F. G., De Michelis, M. I., et al. (2018). Cellular $\mathrm{Ca}^{2+}$ signals generate defined $\mathrm{pH}$ signatures in plants. Plant Cell 30, 2704-2719. doi: 10.1105/tpc.18.00655

Bihler, H., Eing, C., Hebeisen, S., Roller, A., Czempinski, K., and Bertl, A. (2005). TPK1 is a vacuolar ion channel different from the slow-vacuolar cation channel. Plant Physiol. 139, 417-424. doi: 10.1104/pp.105.065599

Bobik, K., Boutry, M., and Duby, G. (2010). Activation of the plasma membrane $\mathrm{H}^{+}$-ATPase by acid stress. Plant Signal. Behav. 5, 681-683. doi: 10.4161/psb.5. 6.11572

Bonales-Alatorre, E., Pottosin, I., Shabala, L., Chen, Z. H., Zeng, F., Jacobsen, S. E., et al. (2013). Differential activity of plasma and vacuolar membrane transporters contributes to genotypic differences in salinity tolerance in a halophyte species, Chenopodium quinoa. Int. J. Mol. Sci. 14, 9267-9285. doi: 10.3390/ijms14059267

Bonza, M. C., and De Michelis, M. I. (2011). The plant $\mathrm{Ca}^{2+}$-ATPase repertoire: biochemical features and physiological functions. Plant Biol. (Stuttg) 13, 421430. doi: 10.1111/j.1438-8677.2010.00405.x the effects of PAs on ion transport across chloroplast membranes have not been addressed. Meanwhile, chloroplasts possess a variety of cation and $\mathrm{K}^{+}$-selective channels in the inner envelope and thylakoid membranes, which finely tune the photosynthesis (for a review, see Checchetto et al., 2013). No data are available on the effects of PAs on mitochondrial ion channels in plants. Plausible PA targets, based on published data on animal mitochondria, involve a mitochondrial $\mathrm{Ca}^{2+}$ uniporter (MCU), controlling mitochondrial $\mathrm{Ca}^{2+}$ homeostasis, metabolism, and cell death (Yan et al., 2015 and references therein; Wagner et al., 2016), a mitochondrial transition pore (Cui et al., 2020), and an ATP- and ROS-sensitive mito $\mathrm{K}_{\mathrm{ATP}}$ channel, whose activity decreases $\Delta \Psi$ and damps mitochondrial ROS production under salinity and drought (Trono et al., 2015).

\section{DATA AVAILABILITY STATEMENT}

The raw data supporting the conclusions of this article will be made available by the authors, without undue reservation.

\section{AUTHOR CONTRIBUTIONS}

IP, OD, and SS developed the concept. MO-A performed the docking analysis. IZ-J composed the table. IP and OD wrote the draft. All authors edited the final version.

Bonza, M. C., Luoni, L., Olivari, C., and De Michelis, M. I. (2016). "Plant type 2B Ca ${ }^{2+}$-ATPases: the diversity of isoforms of the model plant Arabidopsis thaliana," in Regulation of $\mathrm{Ca}^{2+}$-ATPases, V-ATPases and F-ATPases. Advances in Biochemistry in Health and Disease, vol. 14, eds s. Chakraborti, and NS Dhalla (Cham: Springer) doi: 10.1007/978-3-319-24780-9_13

Borrell, A., Culianez-Macia, F. A., Altabella, T., Besford, R. T., Flores, D., and Tiburcio, A. F. (1995). Arginine decarboxylase is localized in chloroplasts. Plant Physiol. 109, 771-776. doi: 10.1104/pp.109.3.771

Bose, J., Babourina, O., Ma, Y., Zhou, M., Shabala, S., and Rengel, Z. (2015a). "Specificity of ion uptake and homeostasis maintenance during acid and aluminium stresses," in Aluminum Stress Adaptation In Plants. Signaling and Communication in Plants, Vol. 24, eds S. Panda and F. Baluška (Cham: Springer), doi: 10.1007/978-3-319-19968-912

Bose, J., Pottosin, I., Shabala, S. S., Palmgren, M. G., and Shabala, S. (2011). Calcium efflux systems in stress signalling and adaptation in plants. Front. Plant Sci. 2, 1-17. doi: 10.3389/fpls.2011.00085

Bose, J., Rodrigo-Moreno, A., Lai, D., Xie, Y., Shen, W., and Shabala, S. (2015b). Rapid regulation of the plasma membrane $\mathrm{H}^{+}$-ATPase activity is essential to salinity tolerance in two halophyte species, Atriplex lentiformis and Chenopodium quinoa. Ann. Bot. 115, 481-494. doi: 10.1093/aob/mc u219

Brüggemann, L. I., Pottosin, I. I., and Schönknecht, G. (1998). Cytoplasmic polyamines block the fast activating vacuolar cation channel. Plant J. 16, 101-106. doi: 10.1046/j.1365-313x.1998.00274.x

Brüggemann, L. I., Pottosin, I. I., and Schönknecht, G. (1999). Selectivity of the fast activating vacuolar cation channel. J. Exp. Bot. 505, 873-876. doi: 10.1093/jxb/ 50.335 .873

Buch-Pedersen, M. J., Rudashevskaya, E. L., Berner, T. S., Venema, K., and Palmgren, M. G. (2006). Potassium as an intrinsic uncoupler of the plasma membrane $\mathrm{H}^{+}$-ATPase. J. Biol. Chem. 281, 38285-38292. doi: 10.1074/jbc. M604781200

Burdach, Z., Siemieniuk, A., and Karcz, W. (2020). Effect of auxin (IAA) on the fast vacuolar (FV) channels in red beet (Beta vulgaris L.) taproot vacuoles. Int. J. Mol. Sci. 21:4876. doi: 10.3390/ijms21144876 
Burdach, Z., Siemieniuk, A., Trela, Z., Kurtyka, R., and Karcz, W. (2018). Role of auxin (IAA) in the regulation of slow vacuolar (SV) channels and the volume of red beet taproot vacuoles. BMC Plant Biol. 18:102. doi: 10.1186/s12870-0181321-6

Chai, H., Guo, J., Zhong, Y., Hsu, C. C., Zou, C., Wang, P., et al. (2020). The plasmamembrane polyamine transporter PUT3 is regulated by the $\mathrm{Na}^{+} / \mathrm{H}^{+}$antiporter SOS1 and protein kinase SOS2. New Phytol. 226, 785-797. doi: 10.1111/nph. 16407

Checchetto, V., Teardo, E., Carraretto, L., Formentin, E., Bergantino, E., Giacometti, G. M., et al. (2013). Regulation of photosynthesis by ion channels in cyanobacteria and higher plants. Biophys. Chem. 182, 51-57. doi: 10.1016/j. bpc. 2013.06 .006

Chen, Z. H., Chen, G., Dai, F., Wang, Y., Hills, A., Ruan, Y. L., et al. (2017). Molecular evolution of grass stomata. Trends Plant Sci. 22, 124-139. doi: 10. 1016/j.tplants.2016.09.005

Chérel, I., and Gaillard, I. (2019). The complex fine-tuning of $\mathrm{K}^{+}$fluxes in plants in relation to osmotic and ionic abiotic stresses. Int. J. Mol. Sci. 20:715. doi: 10.3390/ijms20030715

Choi, W. G., Toyota, M., Kim, S. H., Hilleary, R., and Gilroy, S. (2014). Salt stress-induced $\mathrm{Ca}^{2+}$ waves are associated with rapid, long-distance root-toshoot signaling in plants. Proc. Natl. Acad. Sci. U.S.A. 111, 6497-6502. doi: $10.1073 /$ pnas. 1319955111

Colombo, R., Cerana, R., and Bagni, N. (1992). Evidence for polyamine channels in protoplasts and vacuoles of Arabidopsis thaliana cells. Biochem. Biophys. Res. Commun. 182, 1187-1192. doi: 10.1016/0006-291x(92)91857-m

Corratgé-Faillie, C., Ronzier, E., Sanchez, F., Prado, K., Kim, J. H., Lanciano, S., et al. (2017). The Arabidopsis guard cell outward potassium channel GORK is regulated by CPK33. FEBS Lett. 591, 1982-1992. doi: 10.1002/1873-3468.12687

Costa, A., Luoni, L., Marrano, C. A., Hashimoto, K., Köster P., Giacometti, S., et al. (2017). $\mathrm{Ca}^{2+}$-dependent phosphoregulation of the plasma membrane $\mathrm{Ca}^{2+}$. ATPase ACA8 modulates stimulus-induced calcium signatures. J. Exp. Bot. 68, 3215-3230. doi: 10.1093/jxb/erx162

Cui, J., Pottosin, I., Lamade, E., and Tcherkez, G. (2020). What is the role of putrescine accumulated under potassium deficiency? Plant Cell Environ. 43, 1331-1347. doi: 10.1111/pce.13740

Cuin, T. A., Dreyer, I., and Michard, E. (2018). The role of potassium channels in Arabidopsis thaliana long distance electrical signalling: AKT2 modulates tissue excitability while GORK shapes action potentials. Int. J. Mol. Sci. 19:926. doi: 10.3390/ijms19040926

De Luca, A., Pardo, J. M., and Leidi, E. O. (2018). Pleiotropic effects of enhancing vacuolar K/H exchange in tomato. Physiol. Plant 163, 88-102. doi: 10.1111/ppl. 12656

Demidchik, V. (2014). Mechanisms and physiological roles of $\mathrm{K}^{+}$efflux from root cells. J. Plant Physiol. 171, 696-707. doi: 10.1016/j.jplph.2014.01.015

Demidchik, V. (2018). ROS-Activated ion channels in plants: biophysical characteristics, physiological functions and molecular nature. Int. J. Mol. Sci. 19:1263. doi: 10.3390/ijms19041263

Demidchik, V., Cuin, T. A., Svistunenko, D., Smith, S. J., Miller, A. J., Shabala, S., et al. (2010). Arabidopsis root $\mathrm{K}^{+}$-efflux conductance activated by hydroxyl radicals: single-channel properties, genetic basis and involvement in stress-induced cell death. J. Cell Sci. 123, 1468-1479. doi: 10.1242/jcs. 064352

Demidchik, V., and Maathuis, F. J. M. (2007). Physiological roles of nonselective cation channels in plants: from salt stress to signalling and development. New Phytol. 175, 387-404. doi: 10.1111/j.1469-8137.2007.02128.x

Demidchik, V., Shabala, S., Isayenkov, S., Cuin, T. A., and Pottosin, I. (2018). Calcium transport across plant membranes: mechanisms and functions. New Phytol. 220, 49-69. doi: 10.1111/nph.15266

Demidchik, V., and Tester, M. (2002). Sodium fluxes through non-selective cation channels in the plasma membrane of protoplasts from Arabidopsis thaliana roots. Plant Physiol. 128, 379-387. doi: 10.1104/pp.010524

DiTomaso, J. M., Hart, J. J., and Kochian, L. V. (1992). Transport kinetics and metabolism of exogenously applied putrescine in roots of intact maize seedlings. Plant Physiol. 98, 611-620. doi: 10.1104/pp.98.2.611

Dobrovinskaya, O. R., Muñiz, J., and Pottosin, I. I. (1999a). Asymmetric block of the plant vacuolar $\mathrm{Ca}^{2+}$-permeable channel by organic cations. Eur. Biophys. J. 28, 552-563. doi: 10.1007/s002490050237

Dobrovinskaya, O. R., Muñiz, J., and Pottosin, I. I. (1999b). Inhibition of vacuolar ion channels by polyamines. J. Membr. Biol. 167, 127-140. doi: 10.1007/ s002329900477
Dreyer, I., Gomez-Porras, J. L., and Riedelsberger, J. (2017). The potassium battery: a mobile energy source for transport processes in plant vascular tissues. New Phytol. 216, 1049-1053. doi: 10.1111/nph.14667

Du, H., Zhou, X., Yang, Q., Liu, H., and Kurtenbach, R. (2015). Changes in $\mathrm{H}^{+}$-ATPase activity and conjugated polyamine contents in plasma membrane purified from developing wheat embryos under short-time drought stress. Plant Growth Reg. 75, 1-10. doi: 10.1007/s10725-014-9925-9

Duby, G., and Boutry, M. (2009). The plant plasma membrane proton pump ATPase: a highly regulated P-type ATPase with multiple physiological roles. Pflügers Arch. 457, 645-655. doi: 10.1007/s00424-008-0457-x

Essah, P. A., Davenport, R., and Tester, M. (2003). Sodium influx and accumulation in Arabidopsis. Plant Physiol. 133, 307-318. doi: 10.1104/pp.103.022178

Evans, M. J., Choi, W. G., Gilroy, S., and Morris, R. J. (2016). A ROS-assisted calcium wave dependent on the AtRBOHD NADPH oxidase and TPC1 cation channel propagates the systemic response to salt stress. Plant Physiol. 171, 1771-1784. doi: 10.1104/pp.16.00215

Falhof, J., Pedersen, J. T., Fuglsang, A. T., and Palmgren, M. (2016). Plasma membrane $\mathrm{H}^{+}$-ATPase regulation in the center of plant physiology. Mol. Plant 9, 323-337. doi: 10.1016/j.molp.2015.11.002

Feng, X., Liu, W., Cao, F., Wang, Y., Zhang, G., Chen, Z.-H., et al. (2020). Overexpression of HvAKT1 improves barley drought tolerance by regulating root ion homeostasis and ROS and NO signaling. J. Exp. Bot. 71:eraa354. doi: 10.1093/jxb/eraa354

Foreman, J., Demidchik, V., Bothwell, J. H. F., Mylona, P., Miedema, H., Torres, M. A., et al. (2003). Reactive oxygen species produced by NADPH oxidase regulate plant cell growth. Nature 422, 442-446. doi: 10.1038/nature01485

Fromm, J., Meyer, A. J., and Weisenseel, M. H. (1997). Growth, membrane potential and endogenous ion currents of willow (Salix viminalis) roots are all affected by abscisic acid and spermine. Physiol. Plant 99, 529-537. doi: 10.1111/j.1399-3054.1997.tb05353.x

Fuglsang, A. T., Guo, Y., Cuin, T. A., Qiu, Q., Song, C., Kristiansen, K. A., et al. (2007). Arabidopsis protein kinase PKS5 inhibits the plasma membrane $\mathrm{H}^{+}$. ATPase by preventing interaction with 14-3-3 protein. Plant Cell 19, 1617-1634. doi: $10.1105 /$ tpc. 105.035626

Fujita, M., and Shinozaki, K. (2015). "Polyamine transport systems in plants," in Polyamines, eds T. Kusano and H. Suzuki (Tokyo: Springer), doi: 10.1007/9784-431-55212-315

García-Bossi, J., Kumar, K., Barberini, M. L., Díaz-Domínguez, G., RondónGuerrero, Y., del, C., et al. (2020). The role of P-type IIA and P-type IIB $\mathrm{Ca}^{2+}$-ATPases in plant development and growth. J. Exp. Bot. 71, 1239-1248. doi: $10.1093 /$ jxb/erz521

Garcia-Mata, C., Wang, J., Gajdanowicz, P., Gonzalez, W., Hills, A., Donald, N., et al. (2010). A minimal cysteine motif required to activate the SKOR K${ }^{+}$ channel of Arabidopsis by the reactive oxygen species $\mathrm{H}_{2} \mathrm{O}_{2}$. Int. J. Biol. Chem. 285, 29286-29294. doi: 10.1074/jbc.M110.141176

Garufi, A., Visconti, S., Camoni, L., and Aducci, P. (2007). Polyamines as physiological regulators of 14-3-3 interaction with the plant plasma membrane $\mathrm{H}^{+}$-ATPase. Plant Cell Physiol. 48, 434-440. doi: 10.1093/pcp/pcm010

Gaymard, F., Pilot, G., Lacombe, B., Bouchez, D., Bruneau, D., Boucherez, J., et al. (1998). Identification and disruption of a plant Shaker-like outward channel involved in $\mathrm{K}^{+}$release into the xylem sap. Cell 94, 647-655. doi: 10.1016/s00928674(00)81606-2

Gilliham, M., and Tyerman, S. D. (2016). Linking metabolism to membrane signaling: the GABA-malate connection. Trends Plant Sci. 21, 295-301. doi: 10.1016/j.tplants.2015.11.011

Gjetting, S. K., Mahmood, K., Shabala, L., Kristensen, A., Shabala, S., Palmgren, M., et al. (2020). Evidence for multiple receptors mediating RALF-triggered $\mathrm{Ca}^{2+}$ signaling and proton pump inhibition. Plant J. 104, 433-446. doi: 10.1111/tpj. 14935

Gobert, A., Isayenkov, S., Voelker, C., Czempinski, K., and Maathuis, F. J. M. (2007). The two-pore channel TPK1 gene encodes the vacuolar $\mathrm{K}^{+}$conductance and plays a role in $\mathrm{K}^{+}$homeostasis. Proc. Natl. Acad. Sci. U.S.A. 104, $10726-$ 10731. doi: 10.1073/pnas.0702595104

Grunwald, Y., Wigoda, N., Sade, N., Yaaran, A., Torne, T., Chaka-Gosa, S., et al. (2017). Arabidopsis leaf hydraulic conductance is regulated by xylem-sap pH, controlled, in turn, by a P-type $\mathrm{H}^{+}$-ATPase of vascular bundle sheath cells. bioRxiv [Preprint] doi: 10.1101/234286

Guo, D., and Lu, Z. (2000). Mechanism of cGMP-gated channel block by intracellular polyamines. J. Gen. Physiol. 115, 783-798. doi: 10.1085/jgp.115.6. 783 
Guo, J., Zeng, W., Chen, Q., Lee, C., Chen, L., Yang, Y., et al. (2016). Structure of the voltage-gated two-pore channel TPC1 from Arabidopsis thaliana. Nature 531, 196-201. doi: 10.1038/nature16446

Gupta, K., Sengupta, A., Chakraborty, M., and Gupta, B. (2016). Hydrogen peroxide and polyamines act as double edged swords in plant abiotic stress responses. Front. Plant Sci. 7:1343. doi: 10.3389/fpls.2016.01343

Hamamoto, S., Marui, J., Matsuoka, K., Higashi, K., Igarashi, K., Nakagawa, T., et al. (2008). Characterization of a tobacco TPK-type $\mathrm{K}^{+}$channel as a novel tonoplast $\mathrm{K}^{+}$channel using yeast tonoplasts. J. Biol. Chem. 283, 1911-1920. doi: 10.1074/jbc.M708213200

Hamdani, S., Yaakoubi, H., and Carpentier, R. (2011). Polyamines interaction with thylakoid proteins during stress. J. Photochem. Photobiol. B 104, 314-319. doi: 10.1016/j.jphotobiol.2011.02.007

Haruta, M., and Sussman, M. R. (2012). The effect of a genetically reduced plasma membrane protonmotive force on vegetative growth of Arabidopsis. Plant Physiol. 158, 1158-1171. doi: 10.1104/pp.111.189167

Hedrich, R., and Marten, I. (2011). TPC1 - SV Channels gain shape. Mol. Plant 4, 428-441. doi: 10.1093/mp/ssr017

Hedrich, R., Mueller, T. D., Becker, D., and Marten, I. (2018). Structure and function of TPC1 vacuole SV channel gains shape. Mol. Plant 11, 764-775. doi: 10.1016/j.molp.2018.03.017

Hilleary, R., Paez-Valencia, J., Vens, C., Toyota, M., Palmgren, M., and Gilroy, S. (2020). Tonoplast-localized $\mathrm{Ca}^{2+}$ pumps regulate $\mathrm{Ca}^{2+}$ signals during patterntriggered immunity in Arabidopsis thaliana. PNAS 117, 18849-18857. doi: 10. 1073/pnas.2004183117

Hoffmann, R. D., Olsen, L. I., Ezike, C. V., Pedersen, J. T., Manstretta, R., LópezMarqués, R. L., et al. (2019). Roles of plasma membrane proton ATPases AHA2 and AHA7 in normal growth of roots and root hairs in Arabidopsis thaliana. Physiol Plant 166, 848-861. doi: 10.1111/ppl.12842

Hoffmann, R. D., Portes, M. T., Olsen, L. I., Damineli, D. S. C., Hayashi, M., Nunes, C. O., et al. (2020). Plasma membrane $\mathrm{H}^{+}$-ATPases sustain pollen tube growth and fertilization. Nat. Commun. 11:2395. doi: 10.1038/s41467-020-16253-1

Hosy, E., Vavasseur, A., Mouline, K., Dreyer, I., Gaymard, F., Poree, F., et al. (2003). The Arabidopsis outward $\mathrm{K}^{+}$channel GORK is involved in regulation of stomatal movements and plant transpiration. Proc. Natl. Acad. Sci. U.S.A. 100, 5549-5554. doi: 10.1073/pnas.0733970100

Hu, L., Xiang, L., Zhang, L., Zhou, X., Zou, Z., and Hu, X. (2014). The photoprotective role of spermidine in tomato seedlings under salinity alkalinity stress. PLoS One 9:e110855. doi: 10.1371/journal.pone.0110855

Huang, C. J., and Moczydlowski, E. (2001). Cytoplasmic polyamines as permeant blockers and modulators of the voltage-gated sodium channel. Biophys. J. 80, 1262-1279. doi: 10.1016/S0006-3495(01)76102-4

Igarashi, K., Kashiwagi, K., Kobayashi, H., Ohnishi, R., Kakegawa, T., Nagasu, A., et al. (1989). Effect of polyamines on mitochondrial F1-ATPase catalyzed reactions. J. Biochem. 106, 294-298. doi: 10.1093/oxfordjournals.jbchem. a122847

Inoue, S. I., and Kinoshita, T. (2017). Blue light regulation of stomatal opening and the plasma membrane $\mathrm{H}^{+}$-ATPase. Plant Physiol. 174, 531-538. doi: 10.1104/ pp.17.00166

Ioannidis, N. E., Cruz, J. A., Kotzabasis, K., and Kramer, D. M. (2012). Evidence that putrescine modulates the higher plant photosynthetic proton circuit. PLoS One 7:e29864. doi: 10.1371/journal.pone.0029864

Ioannidis, N. E., Sfichi, L., and Kotzabasis, K. (2006). Putrescine stimulates chemiosmotic ATP synthesis. BBA Bioenergetics 1757, 821-828. doi: 10.1016/ j.bbabio.2006.05.034

Janicka, M. G., Reda, M. G., Czy Ewska, K., and Kaba, A. K. (2018). Involvement of signalling molecules $\mathrm{NO}, \mathrm{H}_{2} \mathrm{O}_{2}$ and $\mathrm{H}_{2} \mathrm{~S}$ in modification of plasma membrane proton pump in cucumber roots subjected to salt or low temperature stress. Funct. Plant Biol. 45, 428-439. doi: 10.1071/FP17095

Janicka-Russak, M., Kabała, K., Młodziñska, E., and Kłobus, G. (2010). The role of polyamines in the regulation of the plasma membrane and the tonoplast proton pumps under salt stress. J. Plant Physiol. 167, 261-269. doi: 10.1016/j. jplph.2009.09.010

Jaślan, D., Dreyer, I., Lu, J., O’Malley, R., Dindas, J., Marten, I., et al. (2019). Voltage-dependent gating of SV channel TPC1 confers vacuole excitability. Nat. Commun. 10:2659. doi: 10.1038/s41467-019-10599-x

Jeandroz, S., Lamotte, O., Astier, J., Rasul, S., Trapet, P., Besson-Bard, A., et al. (2013). There's more to the picture than meets the eye: nitric oxide cross talk with $\mathrm{Ca}^{2+}$ signaling. Plant Physiol. 163, 459-470. doi: 10.1104/pp.113. 220624
Kabała, K., and Kłobus, G. (2005). Plant $\mathrm{Ca}^{2+}$-ATPases. Acta Physiol. Plant. 27, 559-574. doi: 10.1007/s11738-005-0062-y

Keisham, M., Mukherjee, S., and Bhatla, S. C. (2018). Mechanisms of sodium transport in plants-progresses and challenges. Int. J. Mol. Sci. 19:647. doi: 10. 3390/ijms19030647

Kiep, V., Vadassery, J., Lattke, J., Maaß, J. P., Boland, W., Peiter, E., et al. (2015). Systemic cytosolic $\mathrm{Ca}^{2+}$ elevation is activated upon wounding and herbivory in Arabidopsis. New Phytol. 207, 996-1004. doi: 10.1111/nph.13493

Koselski, M., Wasko, P., Kupisz, K., and Trebacz, K. (2019). Cold- and mentholevoked membrane potential changes in the moss Physcomitrella patens: influence of ion channel inhibitors and phytohormones. Physiol. Plant 167, 433-446. doi: 10.1111/ppl.12918

Krueger, S., Giavalisco, P., Krall, L., Steinhauser, M. C., Büssis, D., Usadel, B., et al. (2011). A topological map of the compartmentalized Arabidopsis thaliana leaf metabolome. PLoS One 6:e17806. doi: 10.1371/journal.pone.0017806

Kumari, A., Chételat, A., Nguyen, C. T., and Farmer, E. E. (2019). Arabidopsis $\mathrm{H}^{+}$-ATPase AHA1 controls slow wave potential duration and wound-response jasmonate pathway activation. Proc. Natl. Acad. Sci. U.S.A. 116, 20226-20231. doi: 10.1073/pnas.1907379116

Kwak, J. M., Murata, Y., Baizabal-Aguirre, V. M., Merrill, J., Wang, M., Kemper, A., et al. (2001). Dominant negative guard cell $\mathrm{K}^{+}$channel mutants reduce inwardrectifying $\mathrm{K}^{+}$currents and light-induced stomatal opening in Arabidopsis. Plant Physiol. 127, 473-485. doi: 10.1104/pp.010428

Lenglet, A., Jaślan, D., Toyota, M., Mueller, M., Müller, T., Schönknecht, G., et al. (2017). Control of basal jasmonate signalling and defence through modulation of intracellular cation flux capacity. New Phytol. 216, 1161-1169. doi: 10.1111/ nph.14754

Li, J., Hu, L., Zhang, L., Pan, X., and Hu, X. (2015). Exogenous spermidine is enhancing tomato tolerance to salinity-alkalinity stress by regulating chloroplast antioxidant system and chlorophyll metabolism. BMC Plant Biol. 15:303. doi: 10.1186/s12870-015-0699-7

Li, L., Gu, W., Li, J., Li, C., Xie, T., Qu, D., et al. (2018). Exogenously applied spermidine alleviates photosynthetic inhibition under drought stress in maize (Zea mays L.) seedlings associated with changes in endogenous polyamines and phytohormones. Plant Physiol. Biochem. 129, 35-55. doi: 10.1016/j.plaphy.2018. 05.017

Liu, H. P., Dong, B. H., Zhang, Y. Y., Liu, Z. P., and Liu, Y. L. (2004). Relationship between osmotic stress and the levels of free, conjugated, and bound polyamines in leaves of wheat seedlings. Plant Sci. 166, 1261-1267. doi: 10.1016/j.plantsci. 2003.12.039

Liu, H. P., Yu, B. J., Zhang, W. H., and Liu, Y. L. (2005). Effect of osmotic stress on the activity of $\mathrm{H}^{+}$-ATPase and the levels of covalently and noncovalently conjugated polyamines in plasma membrane preparation from wheat seedling roots. Plant Sci. 168, 1599-1607. doi: 10.1016/j.plantsci.2005.01.024

Liu, J., Yu, B. J., and Liu, Y. L. (2006). Effects of spermidine and spermine levels on salt tolerance associated with tonoplast $\mathrm{H}^{+}$-ATPase and $\mathrm{H}^{+}$-PPase activities in barley roots. Plant Growth Regul. 49, 119-126. doi: 10.1007/s10725-006-9001-1

Liu, K., Fu, H., Bei, Q., and Luan, S. (2000). Inward potassium channel in guard cells as a target for polyamine regulation of stomatal movements. Plant Physiol. 124, 1315-1325. doi: 10.1104/pp.124.3.1315

Liu, M. Y., Sun, J., Wang, K. Y., Liu, D., Li, Z. Y., and Zhang, J. (2014). Spermidine enhances waterlogging tolerance via regulation of antioxidant defense, heat shock protein expression and plasma membrane $\mathrm{H}^{+}$-ATPase activity in Zea mays. J. Agro. Crop Sci. 200, 199-211. doi: 10.1111/jac.12058

Maathuis, F. J. (2011). Vacuolar two-pore $\mathrm{K}^{+}$channels act as vacuolar osmosensors. New Phytol. 191, 84-91. doi: 10.1111/j.1469-8137.2011.03664.x

Maksimović, J. D., Zhang, J., Zeng, F., Živanović, B. D., Shabala, L., Zhou, M., et al. (2013). Linking oxidative and salinity stress tolerance in barley: can root antioxidant enzyme activity be used as a measure of stress tolerance? Plant Soil 365, 141-155. doi: 10.1007/s11104-012-1366-5

Marina, M., Maiale, S. J., Rossi, F. R., Romero, M. F., Rivas, E. I., Gárriz, A., et al. (2008). Apoplastic polyamine oxidation plays different roles in local responses of tobacco to infection by the necrotrophic fungus Sclerotinia sclerotiorum and the biotrophic bacterium Pseudomonas viridiflava. Plant Physiol. 147, 2164-2178. doi: 10.1104/pp.108.122614

Marty, F. (1999). Plant vacuoles. Plant Cell 11, 587-599. doi: 10.1105/tpc.11.4.587

Meksuriyen, D., Fukuchi-Shimogori, T., Tomitori, H., Kashiwagi, K., Toida, T., Imanari, T., et al. (1998). Formation of a complex containing ATP, $\mathrm{Mg}^{2+}$, and spermine. Structural evidence and biological significance. J. Biol. Chem. 273, 30939-30944. doi: 10.1074/jbc.273.47.30939 
Miśkiewicz, J., Trela, Z., Burdach, Z., Karcz, W., and Balińska-Miśkiewicz, W. (2020). Long range correlations of the ion current in SV channels. $\mathrm{Met}_{3} \mathrm{PbCl}$ influence study. PLoS One 15:e0229433. doi: 10.1371/journal.pone.022 9433

Moschou, P. N., Paschalidis, K. A., and Roubelakis-Angelakis, K. A. (2008). Plant polyamine catabolism: the state of the art. Plant Signal. Behav. 3, 1061-1066. doi: $10.4161 / \mathrm{psb} \cdot 3 \cdot 12.7172$

Moschou, P. N., Sarris, P. F., Skandalis, N., Andriopoulou, A. H., Paschalidis, K. A., Panopoulos, N. J., et al. (2009). Engineered polyamine catabolism preinduces tolerance of tobacco to bacteria and oomycetes. Plant Physiol. 149, 1970-1981. doi: 10.1104/pp.108.134932

Moschou, P. N., Wu, J., Cona, A., Tavladoraki, P., Angelini, R., and RoubelakisAngelakis, K. A. (2012). The polyamines and their catabolic products are significant players in the turnover of nitrogenous molecules in plants. J. Exp. Bot. 63, 5003-5015. doi: 10.1093/jxb/ers202

Ozawa, R., Bertea, C. M., Foti, M., Narayana, R., Arimura, G., Muroi, A., et al. (2010). Polyamines and jasmonic acid induce plasma membrane potential variations in lima bean. Plant Signal. Behav. 5, 308-310. doi: 10.4161/psb.5.3. 10848

Pál, M., Szalai, G., and Janda, T. (2015). Speculation: polyamines are important in abiotic stress signaling. Plant Sci. 237, 16-23. doi: 10.1016/j.plantsci.2015.05. 003

Palmgren, M., and Morsomme, P. (2018). The plasma membrane $\mathrm{H}^{+}$-ATPase, a simple polypeptide with a long history. Yeast 36, 201-210. doi: 10.1002/yea. 3365

Pandolfi, C., Pottosin, I., Cuin, T., Mancuso, S., and Shabala, S. (2010). Specificity of polyamine effects on $\mathrm{NaCl}$-induced ion flux kinetics and salt stress amelioration in plants. Plant Cell Physiol. 51, 422-434. doi: 10.1093/pcp/pcq007

Paschalidis, K., Tsaniklidis, G., Wang, B. Q., Delis, C., Trantas, E., Loulakakis, K., et al. (2019). The interplay among polyamines and nitrogen in plant stress responses. Plants (Basel) 8:315. doi: 10.3390/plants8090315

Pei, Z.-M., Murata, Y., Benning, G., Thomine, S. Â, Klüsener, B., Gethyn, J., et al. (2000). Calcium channels activated by hydrogen peroxide mediate abscisic acid signalling in guard cells. Nature 406, 731-734. doi: 10.1038/35021067

Peiter, E. (2011). The plant vacuole: emitter and receiver of calcium signals. Cell Calcium 50, 120-128. doi: 10.1016/j.ceca.2011.02.002

Peiter, E., Maathuis, F., Mills, L., Knight, H., Pelloux, J., Hetherington, A. M., et al. (2005). The vacuolar $\mathrm{Ca}^{2+}$-activated channel TPC1 regulates germination and stomatal movement. Nature 434, 404-408. doi: 10.1038/nature03381

Peter, H. W., Pinheiro, M. R., and Silva-Lima, M. (1981). Regulation of the F-ATPase from mitochondria of Vigna sinensis (L.) Savi cv. Pitiuba by spermine, spermidine, putrescine, $\mathrm{Mg}^{2+}, \mathrm{Na}^{+}$, and $\mathrm{K}^{+}$. Can. J. Biochem. 59, 60-66. doi: 10.1139/o81-009

Pistocchi, R., Bagni, N., and Creus, J. A. (1987). Polyamine uptake in carrot cell cultures. Plant Physiol. 84, 374-380. doi: 10.1104/pp.84.2.374

Pottosin, I. (2015). "Polyamine action on plant ion channels and pumps," in Polyamines, eds T. Kusano and H. Suzuki (Tokyo: Springer), doi: 10.1007/9784-431-55212-319

Pottosin, I., and Dobrovinskaya, O. (2014). Non-selective cation channels in plasma and vacuolar membranes and their contribution to $\mathrm{K}^{+}$transport. J. Plant Physiol. 171, 732-742. doi: 10.1016/j.jplph.2013.11.013

Pottosin, I., and Dobrovinskaya, O. (2018). Two-pore cation (TPC) channel: not a shorthanded one. Funct. Plant Biol. 45, 83-92. doi: 10.1071/FP16338

Pottosin, I., and Shabala, S. (2014). Polyamines control of cation transport across plant membranes: implications for ion homeostasis and abiotic stress signaling. Front. Plant Sci. 5:154. doi: 10.3389/fpls.2014.00154

Pottosin, I., Velarde-Buendía, A. M., Bose, J., Fuglsang, A. T., and Shabala, S. (2014a). Polyamines cause plasma membrane depolarization, activate $\mathrm{Ca}^{2+}$, and modulate $\mathrm{H}^{+}$-ATPase pump activity in pea roots. J. Exp. Bot. 65, 24632472. doi: $10.1093 / \mathrm{jxb} / \mathrm{eru} 133$

Pottosin, I., Velarde-Buendía, A. M., Bose, J., Zepeda -Jazo, I., Shabala, S., and Dobrovinskaya, O. (2014b). Cross-talk between reactive oxygen species and polyamines in regulation of ion transport across the plasma membrane: implications for plant adaptive responses. J. Exp. Bot. 65, 1271-1283. doi: 10. 1093/jxb/ert423

Pottosin, I., Velarde-Buendia, A. M., Zepeda-Jazo, I., Dobrovinskaya, O., and Shabala, S. (2012). Synergism between polyamines and ROS in the induction of $\mathrm{Ca}^{2+}$ and $\mathrm{K}^{+}$fluxes in roots. Plant Signal. Behav. 7, 1084-1087. doi: 10.4161/ psb. 21185

Pottosin, I., and Zepeda-Jazo, I. (2018). Powering the plasma membrane $\mathrm{Ca}^{2+}$-ROS self-amplifying loop. J. Exp. Bot. 69, 3317-3320. doi: 10.1093/jxb/ery179

Pottosin, I., Zepeda-Jazo, I., Bose, J., and Shabala, S. (2018). An anion conductance, the essential component of the hydroxyl-radical-induced ion current in plant roots. Int. J. Mol. Sci. 19:897. doi: 10.3390/ijms19030897

Pottosin, I. I., and Martínez-Estévez, M. (2003). Regulation of the fast vacuolar channel by cytosolic and vacuolar potassium. Biophys. J. 84, 977-986. doi: 10.1016/S0006-3495(03)74914-5

Pottosin, I. I., Martínez-Estévez, M., Dobrovinskaya, O. R., and Muñiz, J. (2003). Potassium-selective channel in the red beet vacuolar membrane. J. Exp. Bot. 54, 663-667. doi: 10.1093/jxb/erg067

Pottosin, I. I., and Muñiz, J. (2002). Higher plant vacuolar ionic transport in the cellular context. Acta Bot. Mex. 60, 37-77. doi: 10.21829/abm60.2002.902

Raddatz, N., Morales de Los Ríos, L., Lindahl, M., Quintero, F. J., and Pardo, J. M. (2020). Coordinated transport of nitrate, potassium, and sodium. Front. Plant Sci. 11:247. doi: 10.3389/fpls.2020.00247

Ragel, P., Raddatz, N., Leidi, E. O., Quintero, F. J., and Pardo, J. M. (2019). Regulation of $\mathrm{K}^{+}$nutrition in plants. Front. Plant Sci. 10:281. doi: 10.3389/fpls. 2019.00281

Ramesh, S., Tyerman, S., Xu, B., Bose, J., Kaur, S., Conn, V., et al. (2015). GABA signalling modulates plant growth by directly regulating the activity of plantspecific anion transporters. Nat. Commun. 6:7879. doi: 10.1038/ncomms8879

Reggiani, R., Zaina, S., and Bertani, A. (1992). Plasmalemma ATPase in rice coleoptiles: stimulation by putrescine and polyamines. Phytochemistry 31, 417419. doi: 10.1016/0031-9422(92)90009-F

Rodrigo-Moreno, A., Andrés-Colás, N., Poschenrieder, C., Gunsé, B., Peñarrubia, L., and Shabala, S. (2013). Calcium- and potassium-permeable plasma membrane transporters are activated by copper in Arabidopsis root tips: linking copper transport with cytosolic hydroxyl radical production. Plant Cell Environ. 36, 844-855. doi: 10.1111/pce.12020

Rodríguez, A. A., Maiale, S. J., Menédez, A. B., and Ruiz, O. A. (2009). Polyamine oxidase activity contributes to sustain maize leaf elongation under saline stress. J. Exp. Bot. 60, 4249-4262. doi: 10.1093/jxb/erp256

Roy, P., Niyogi, K., Sengupta, D. N., and Ghosh, B. (2005). Spermidine treatment to rice seedlings recovers salinity stress-induced damage of plasma membrane and PM-bound $\mathrm{H}^{+}$-ATPase in salt- tolerant and salt-sensitive rice cultivars. Plant Sci. 168, 583-591. doi: 10.1016/j.plantsci.2004.08.014

Rubio, F., Nieves-Cordones, M., Horie, T., and Shabala, S. (2020). Doing 'business as usual' comes with a cost: evaluating energy cost of maintaining plant intracellular $\mathrm{K}^{+}$homeostasis under saline conditions. New Phytol. 225, $1097-$ 1104. doi: 10.1111/nph.15852

Schiøtt, M., and Palmgren, M. G. (2005). Two plant $\mathrm{Ca}^{2+}$ pumps expressed in stomatal guard cells show opposite expression patterns during cold stress. Physiol. Plant 124, 278-283. doi: 10.1111/j.1399-3054.2005.00512.x

Seifikalhor, M., Aliniaeifard, S., Bernard, F., Mehdi, S., Mojgan, L., Batool, H., et al. (2020). $\gamma$-Aminobutyric acid confers cadmium tolerance in maize plants by concerted regulation of polyamine metabolism and antioxidant defense systems. Sci. Rep. 10:3356. doi: 10.1038/s41598-020-59592-1

Seifikalhor, M., Aliniaeifard, S., Shomali, A., Azad, N., Hassani, B., Lastochkinaet, O., et al. (2019). Calcium signaling and salt tolerance are diversely entwined in plants. Plant Signal. Behav. 14:11. doi: 10.1080/15592324.2019.1665455

Shabala, S. (2017). Signalling by potassium: another second messenger to add to the list? J. Exp. Bot. 68, 4003-4007. doi: 10.1093/jxb/erx238

Shabala, S., Chen, G., Chen, Z. -H., and Pottosin, I. (2020). The energy cost of the tonoplast futile sodium leak. New Phytol. 225, 1105-1110. doi: 10.1111/nph. 15758

Shabala, S., and Cuin, T. A. (2008). Potassium transport and plant salt tolerance. Physiol. Plant 133, 651-669. doi: 10.1111/j.1399-3054.2007.01008.x

Shabala, S., Cuin, T. A., and Pottosin, I. I. (2007a). Polyamines prevent NaClinduced $\mathrm{K}^{+}$efflux from pea mesophyll by blocking non-selective cation channels. FEBS Lett. 581, 1993-1999. doi: 10.1016/j.febslet.2007.04.032

Shabala, S., Cuin, T. A., Prismall, L., and Nemchinov, L. G. (2007b). Expression of animal CED-9 anti-apoptotic gene in tobacco modifies plasma membrane ion fluxes in response to salinity and oxidative stress. Planta 227, 189-197. doi: 10.1007/s00425-007-0606-Z 
Shabala, S., Shabala, L., Barcelo, J., and Poschenrieder, C. (2014). Membrane transporters mediating root signalling and adaptive responses to oxygen deprivation and soil flooding. Plant Cell Environ. 37, 2216-2233. doi: 10.1111/ pce. 12339

Sharma, T., Dreyer, I., and Riedelsberger, J. (2013). The role of $\mathrm{K}^{+}$channels in uptake and redistribution of potassium in the model plant Arabidopsis thaliana. Front. Plant Sci. 4:224. doi: 10.3389/fpls.2013.00224

Shelp, B. J., Bozzo, G. G., Trobacher, C. P., Zarei, A., Deyman, K. L., and Brikis, C. J. (2012). Hypothesis/review: contribution of putrescine to 4-aminobutyrate (GABA) production in response to abiotic stress. Plant Sci. 19, 130-135. doi: 10.1016/j.plantsci.2012.06.001

Shu, S., Yuan, Y., Chen, J., Sun, J., Zhang, W., Tang, Y., et al. (2015). The role of putrescine in the regulation of proteins and fatty acids of thylakoid membranes under salt stress. Sci. Rep. 5:14390. doi: 10.1038/srep14390

Srivastava, S. K., and Rajbabu, P. (1983). Effect of amines and guanidines on ATPase from maize scutellum. Phytochemistry 22, 2375-2679. doi: 10.1016/ S0031-9422(00)97671-4

Su, N., Wu, Q., Chen, J., Shabala, L., Mithöfer, A., Wang, H., et al. (2019). GABA operates upstream of $\mathrm{H}^{+}$-ATPase and improves salinity tolerance in Arabidopsis by enabling cytosolic $\mathrm{K}^{+}$retention and $\mathrm{Na}^{+}$exclusion. J. Exp. Bot. 70, 6349-6361. doi: 10.1093/jxb/erz367

Sudha, G., and Ravishankar, G. A. (2003). Influence of putrescine on anthocyanin production in callus cultures of Daucus carota mediated through calcium ATPase. Acta Physiol. Plant 25, 69-75. doi: 10.1007/s11738-003-0038-8

Suh, B. C., and Hille, B. (2008). PIP 2 is a necessary cofactor for ion channel function: how and why? Annu. Rev. Biophys. 37, 175-195. doi: 10.1146/annurev. biophys.37.032807.125859

Sun, C., Liu, Y. L., and Zhang, W. H. (2002). Mechanism of the effect of polyamines on the activity of tonoplasts of barley roots under salt stress. Acta Bot. Sin. 44, 1167-1172.

Takahashi, T., and Kakehi, J. (2010). Polyamines: ubiquitous polycations with unique roles in growth and stress responses. Ann. Bot. 105, 1-6. doi: 10.1093/ aob/mcp259

Takeda, S., Gapper, C., Kaya, H., Bell, E., Kuchitsu, K., and Dolan, L. (2008). Local positive feedback regulation determines cell shape in root hair cells. Science 319, 1241-1244. doi: 10.1126/science. 1152505

Tang, R., Zhao, F., Yang, Y., Wang, C., Li, K., Kleist, T. J., et al. (2020). A calcium signalling network activates vacuolar $\mathrm{K}^{+}$remobilization to enable plant adaptation to low-K environments. Nat. Plants 6, 384-393. doi: 10.1038/ s41477-020-0621-7

Tang, W., and Newton, R. J. (2005). Polyamines reduce salt-induced oxidative damage by increasing the activities of antioxidant enzymes and decreasing lipid peroxidation in Virginia pine. Plant Growth Reg. 46, 31-43. doi: 10.1007/ s10725-005-6395-0

Tavladoraki, P., Cona, A., Federico, R., Tempera, G., Viceconte, N., Saccoccio, S., et al. (2012). Polyamine catabolism: target for antiproliferative therapies in animals and stress tolerance strategies in plants. Amino Acids 42, 411-426. doi: 10.1007/s00726-011-1012-1

Tikhonova, L. I., Pottosin, I. I., Dietz, K. J., and Schönknecht, G. (1997). Fastactivating cation channel in barley mesophyll vacuoles. Inhibition by calcium. Plant J. 11, 1059-1070. doi: 10.1046/j.1365-313X.1997.11051059.x

Trono, D., Laus, M. N., Soccio, M., Alfarano, M., and Pastore, D. (2015). Modulation of potassium channel activity in the balance of ROS and ATP production by durum wheat mitochondria-An amazing defense tool against hyperosmotic stress. Front. Plant Sci. 6:1072. doi: 10.3389/fpls.2015. 01072

Velarde-Buendía, A. M., Shabala, S., Cvikrova, M., Dobrovinskaya, O., and Pottosin, I. (2012). Salt-sensitive and salt-tolerant barley varieties differ in the extent of potentiation of the ROS-induced $\mathrm{K}^{+}$efflux by polyamines. Plant Physiol. Biochem. 61, 18-23. doi: 10.1016/j.plaphy.2012.09.002

Wagner, S., De Bortoli, S., Schwarzländer, M., and Szabò, I. (2016). Regulation of mitochondrial calcium in plants versus animals. J. Exp. Bot. 67, 3809-3829. doi: $10.1093 /$ jxb/erw100

Wang, C., Fan, L., Gao, H., Wu, X., Li, J., Lv, G., et al. (2014). Polyamine biosynthesis and degradation are modulated by exogenous gammaaminobutyric acid in root-zone hypoxia-stressed melon roots. Plant Physiol. Biochem. 82, 17-26. doi: 10.1016/j.plaphy.2014.04.018
Wang, F., Chen, Z. H., and Shabala, S. (2017). Hypoxia sensing in plants: on a quest for ion channels as putative oxygen sensors. Plant Cell Physiol. 58, 1126-1142. doi: $10.1093 / \mathrm{pcp} / \mathrm{pcx} 079$

Wang, W., Tian, F., Hao, Q., Han, Y., Li, Q., Wang, X., et al. (2018). Improved salt tolerance in a wheat stay-green mutant tasg1. Acta Physiol. Plant 40:39. doi: 10.1007/s11738-018-2617-8

Wang, Y., Blatt, M. R., and Chen, Z.-H. (2018). "Ion transport at the plant plasma membrane," in eLS, (Chichester: John Wiley \& Sons, Ltd.), doi: 10.1002/ 9780470015902.a0001307.pub3

Wang, Y., and Wu, W. H. (2013). Potassium transport and signaling in higher plants. Annu. Rev. Plant Biol. 64, 451-476. doi: 10.1146/annurev-arplant050312-120153

Ward, J. M., and Schroeder, J. I. (1994). Calcium-activated $\mathrm{K}^{+}$channels and calcium-induced calcium release by slow vacuolar ion channels in guard cell vacuoles implicated in the control of stomatal closure. Plant Cell 6, 669-683. doi: 10.1105/tpc.6.5.669

Wherrett, T., Shabala, S., and Pottosin, I. (2005). Different properties of SV channels in root vacuoles from near isogenic Al-tolerant and Al-sensitive wheat cultivars. FEBS Lett. 579, 6890-6894. doi: 10.1016/j.febslet.2005.11.038

Williams, K. (1997). Interactions of polyamines with ion channels. Biochem. J. 325, 289-297. doi: 10.1042/bj3250289

Wu, J., Shang, Z., Wu, J., Jiang, X., Moschou, P. N., Sun, W., et al. (2010). Spermidine oxidase-derived $\mathrm{H}_{2} \mathrm{O}_{2}$ regulates pollen plasma membrane hyperpolarization-activated $\mathrm{Ca}^{2+}$-permeable channels and pollen tube growth. Plant J. 63, 1042-1053. doi: 10.1111/j.1365-313X.2010.04301.x

Wu, L. B., Holtkamp, F., Wairich, A., and Frei, M. (2019). Potassium ion channel gene OsAKT1 affects iron translocation in rice plants exposed to iron toxicity. Front. Plant Sci. 10:579. doi: 10.3389/fpls.2019.00579

Wu, X., Shu, S., Wang, Y., Yuan, R., and Guo, S. (2019). Exogenous putrescine alleviates photoinhibition caused by salt stress through cooperation with cyclic electron flow in cucumber. Photosynth. Res. 141, 303-314. doi: 10.1007/s11120019-00631

Xie, L. H., John, S. A., Ribalet, B., and Weiss, J. N. (2005). Long polyamines act as cofactors in $\mathrm{PIP}_{2}$ activation of inward rectifier potassium (Kir2.1) channels. J. Gen. Physiol. 126, 541-549. doi: 10.1085/jgp.200509380

Xu, W., Jia, L., Baluška, F., Ding, G., Shi, W., Ye, N., et al. (2012). PIN 2 is required for the adaptation of Arabidopsis roots to alkaline stress by modulating proton secretion. J. Exp. Bot. 63, 6105-6114. doi: 10.1093/jxb/ers259

Xu, W., Jia, L., Shi, W., Liang, J., Zhou, F., Li, Q., et al. (2013). Abscisic acid accumulation modulates auxin transport in the root tip to enhance proton secretion for maintaining root growth under moderate water stress. New Phytol. 197, 139-150. doi: 10.1111/nph.12004

Yamauchi, S., and Shimazaki, K. (2017). Determination of $\mathrm{H}^{+}$-ATPase activity in Arabidopsis guard cell protoplasts through $\mathrm{H}^{+}$-pumping measurement and $\mathrm{H}^{+}$-ATPase quantification. Bio protocol 7:e2653. doi: 10.21769/BioProtoc.2653

Yamauchi, S., Takemiya, A., Sakamoto, T., Kurata, T., Tsutsumi, T., Kinoshita, T., et al. (2016). The plasma membrane $\mathrm{H}^{+}$-ATPase AHA1 plays a major role in stomatal opening in response to blue light. Plant Physiol. 171, 2731-2743. doi: 10.1104/pp.16.01581

Yan, H., Zhang, D., Hao, S., Li, K., and Hang, C. H. (2015). Role of mitochondrial calcium uniporter in early brain injury after experimental subarachnoid hemorrhage. Mol. Neurobiol. 52, 1637-1647. doi: 10.1007/s12035-014-8942-Z

Yang, D. L., Shi, Z., Bao, Y., Yan, J., Yang, Z., Yu, H., et al. (2017). Calcium pumps and interacting BON1 protein modulate calcium signature, stomatal closure, and plant immunity. Plant Physiol. 175, 424-437. doi: 10.1104/pp.17.00495

Yang, Y., Wu, Y., Ma, L., Yang, Z., Dong, Q., Li, Q., et al. (2019). The $\mathrm{Ca}^{2+}$ sensor $\mathrm{SCaBP}_{3} / \mathrm{CBL}_{7}$ modulates plasma membrane $\mathrm{H}^{+}$-ATPase activity and promotes alkali tolerance in Arabidopsis. Plant Cell 31, 1367-1384. doi: 10.1105/tpc.18. 00568

Yoda, H., Hiroi, Y., and Sano, H. (2006). Polyamine oxidase is one of the key elements for oxidative burst to induce programmed cell death in tobacco cultured cells. Plant Physiol. 142, 193-206. doi: 10.1104/pp.106.080515

Yu, H., Yan, J., Du, X., and Hua, J. (2018). Overlapping and differential roles of plasma membrane calcium ATPases in Arabidopsis growth and environmental responses. J. Exp. Bot. 69, 2693-2703. doi: 10.1093/jxb/ery073

Zarza, X., Shabala, L., Fujita, M., Shabala, S., Haring, M. A., Tiburcio, A. F., et al. (2019). Extracellular spermine triggers a rapid intracellular phosphatidic acid 
response in Arabidopsis, involving PLD $\delta$ activation and stimulating ion flux. Front. Plant Sci. 10:601. doi: 10.3389/fpls.2019.00601

Zarza, X., Van Wijk, R., Shabala, L., Hunkeler, A., Lefebvre, M., Rodriguez-Villalón, A., et al. (2020). Lipid kinases $\mathrm{PIP}_{5} \mathrm{~K}_{7}$ and $\mathrm{PIP}_{5} \mathrm{~K}_{9}$ are required for polyaminetriggered $\mathrm{K}^{+}$efflux in Arabidopsis roots. Plant J. 104, 416-432. doi: 10.1111/tpj. 14932

Zepeda-Jazo, I., Shabala, S., Chen, Z., and Pottosin, I. I. (2008). Na-K transport in roots under salt stress. Plant Signal. Behav. 3, 401-403. doi: 10.4161/psb.3.6. 5429

Zepeda-Jazo, I., Velarde-Buendia, A. M., Enriquez-Figueroa, R., Bose, J., Shabala, S., Muniz-Murguia, J., et al. (2011). Polyamines interact with hydroxyl radicals in activating $\mathrm{Ca}^{2+}$ and $\mathrm{K}^{+}$transport across the root epidermal plasma membranes. Plant Physiol. 157, 2167-2180. doi: 10.1104/pp.111. 179671

Zhang, J., Wei, J., Li, D., Kong, X., Rengel, Z., Chen, L., et al. (2017). The role of the plasma membrane $\mathrm{H}^{+}$-ATPase in plant responses to aluminum toxicity. Front. Plant Sci. 8:1757. doi: 10.3389/fpls.2017.01757

Zhang, Y., Lv, Y., Jahan, N., Chen, G., Ren, D., and Guo, L. (2018). Sensing of abiotic stress and ionic stress responses in plants. Int. J. Mol. Sci. 19:3298. doi: 10.3390/ijms19113298

Zhao, F., and Qin, P. (2004). Protective effect of exogenous polyamines on root tonoplast function against salt stress in barley seedlings. Plant Growth Regul. 42, 97-103. doi: 10.1023/B:GROW.0000017478.40445.bc
Zhao, F., Song, C. P., He, J., and Zhu, H. (2007). Polyamines improve $\mathrm{K}^{+} / \mathrm{Na}^{+}$ homeostasis in barley seedlings by regulating root ion channel activities. Plant Physiol. 145, 1061-1072. doi: 10.1104/pp.107.105882

Zhu, C., Yang, N., Ma, X., Li, G., Qian, M., Ng, D., et al. (2015). Plasma membrane $\mathrm{H}^{+}$-ATPase is involved in methyl jasmonate-induced root hair formation in lettuce (Lactuca sativa L.) seedlings. Plant Cell Rep. 34, 1025-1036. doi: 10.1007/ s00299-015-1762-4

Zhu, X., Caplan, J., Mamillapalli, P., Czymmek, K., and Dinesh-Kumar, S. P. (2010). Function of endoplasmic reticulum calcium ATPase in innate immunitymediated programmed cell death. EMBO J. 29, 1007-1018. doi: 10.1038/emboj. 2009.402

Conflict of Interest: The authors declare that the research was conducted in the absence of any commercial or financial relationships that could be construed as a potential conflict of interest.

Copyright (c) 2021 Pottosin, Olivas-Aguirre, Dobrovinskaya, Zepeda-Jazo and Shabala. This is an open-access article distributed under the terms of the Creative Commons Attribution License (CC BY). The use, distribution or reproduction in other forums is permitted, provided the original author(s) and the copyright owner(s) are credited and that the original publication in this journal is cited, in accordance with accepted academic practice. No use, distribution or reproduction is permitted which does not comply with these terms. 